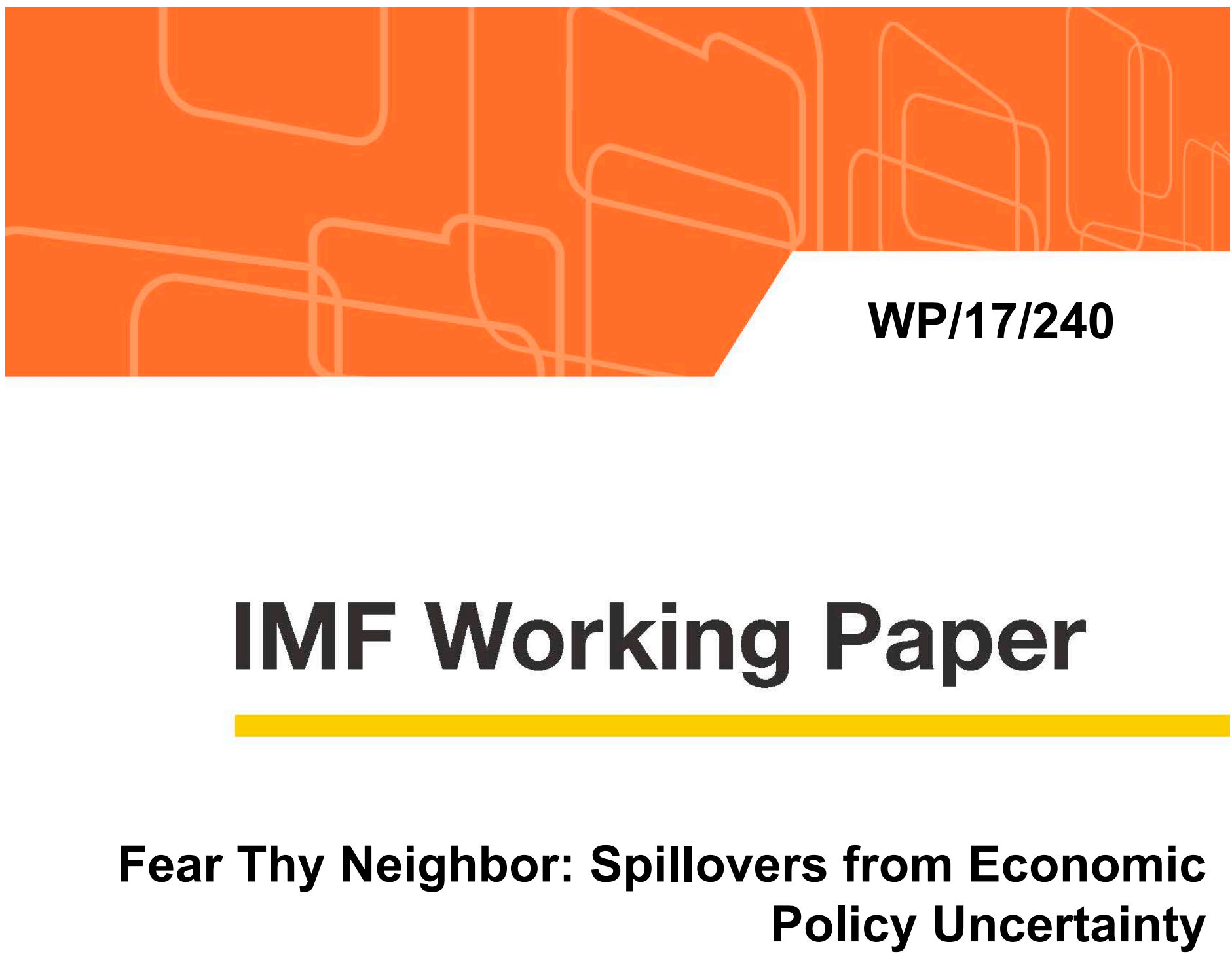

by Nina Biljanovska, Francesco Grigoli, Martina Hengge

IMF Working Papers describe research in progress by the author(s) and are published to elicit comments and to encourage debate. The views expressed in IMF Working Papers are those of the author(s) and do not necessarily represent the views of the IMF, its Executive Board, or IMF management.
I N
$N T E R$
N A T I O N A L
$M O N E$ T A R Y
F U N D 


\title{
Fear Thy Neighbor: Spillovers from Economic Policy Uncertainty*
}

\author{
Nina Biljanovska ${ }^{\dagger} \quad$ Francesco Grigoli ${ }^{\ddagger} \quad$ Martina Hengge ${ }^{\S}$
}

\begin{abstract}
High levels of economic policy uncertainty in various parts of the world revamped the debate about its impact on economic activity. With increasingly stronger economic, financial, and political ties among countries, economic agents have more reasons to be vigilant of foreign economic policy. Employing heterogeneous panel structural vector autoregressions, this paper tests for spillovers from economic policy uncertainty on other countries' economic activity. Furthermore, using local projections, the paper zooms in on shocks originating in the United States, Europe, and China. Our results suggest that economic policy uncertainty reduces growth in real output, private consumption, and private investment, and that spillovers from abroad account for about two-thirds of the negative effect. Moreover, uncertainty in the United States, Europe, and China reduces economic activity in the rest of the world, with the effects being mostly felt in Europe and the Western Hemisphere.
\end{abstract}

Keywords: Economic policy uncertainty, China, Europe, private consumption, private investment, spillover, United States.

JEL Codes: D80, E32, F42.

* The views expressed in this Working Paper are those of the authors and do not necessarily represent those of the IMF or IMF policy. Working Papers describe research in progress by the authors and are published to elicit comments and to encourage debate. We thank, without implicating, Lisandro Abrego, Sergei Antoshin, Ashok Vir Bhatia, Pelin Berkman, Rodrigo Cubero, Alfredo Cuevas, Shilei Fan, Davide Furceri, Florence Jaumotte, Daniel Leigh, Troy Matheson, Carola Moreno, Luca Ricci, Antonio Spilimbergo, Esteban Vesperoni and the participants of the IMF seminar held in August 2017 for their comments and suggestions.

${ }^{\dagger}$ International Monetary Fund, Western Hemisphere Department, nbijanovska@imf.org.

${ }^{\ddagger}$ International Monetary Fund, Research Department, fgrigoli@imf.org.

$\S$ The Graduate Institute, martina.hengge@graduateinstitute.ch. 


\section{Contents}

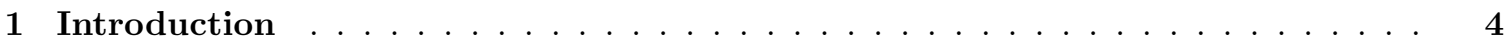

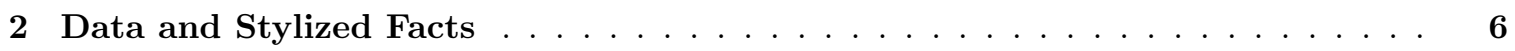

3 Econometric Analysis . . . . . . . . . . . . . . . . . . . 9

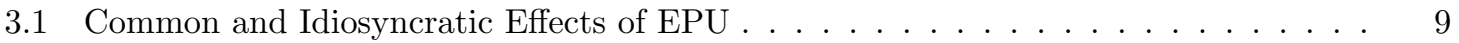

3.1 .1 Heterogeneous PSVAR . . . . . . . . . . . . . . . . . . 9

3.1 .2 Estimation Results . . . . . . . . . . . . . . . . . . . . . . . . 11

3.2 Spillovers of EPU from the US, Europe, and China . . . . . . . . . . . . . . . 13

$3.2 .1 \quad$ Local Projections . . . . . . . . . . . . . . . . . . . . . . . 13

3.2 .2 Estimation Results . . . . . . . . . . . . . . . . . . . . . 15

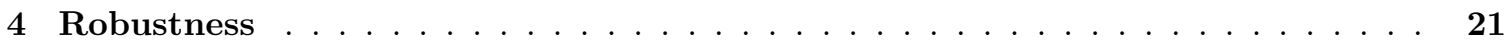

4.1 Heterogeneous PSVAR . . . . . . . . . . . . . . . . . . . . . 21

4.2 Local Projections . . . . . . . . . . . . . . . . . . . . . . 23

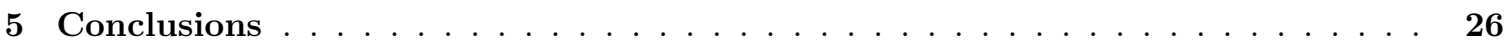

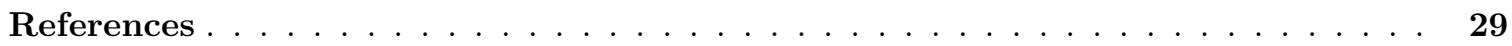

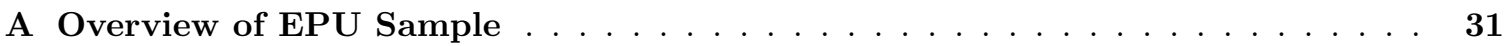

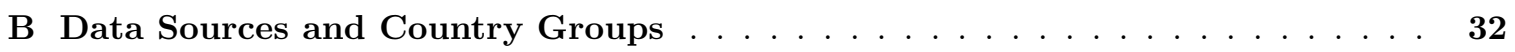

\section{List of Figures}

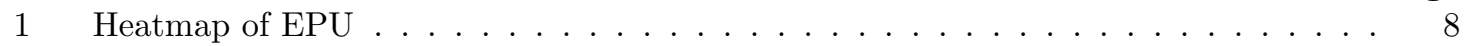

2 EPU and Macroeconomic Aggregates . . . . . . . . . . . . . . . . 9

3 Correlations between EPU in the US, Europe, and China and Regional Macroeconomic Aggregates (Percent) . . . . . . . . . . . . . . . . . . . 10

4 IRF Distribution from Heterogeneous PSVAR (Percent) $\ldots \ldots \ldots \ldots \ldots$

5 Bootstrap of Heterogeneous PSVAR (Percent) . . . . . . . . . . . . . . . . . 13

6 Median Effect Decomposition from Heterogeneous PSVAR (Percent) . . . . . . . . . 14

7 Spillovers from an EPU Shock in the US, Europe, and China (Percent) . . . . . . . . 16

8 Spillovers from an EPU Shock in the US across Regions with Annual Data (Percent) 18

9 Spillovers from an EPU Shock in Europe across Regions with Annual Data (Percent) 19

10 Spillovers from an EPU Shock in China across Regions with Annual Data (Percent) 20

11 IRFs from Heterogeneous PSVAR with Controls for General Uncertainty, Activity, and Confidence (Percent) . . . . . . . . . . . . . . . . . . 23

12 Inverted Ordering of Endogenous Regressors in Heterogeneous PSVAR . . . . . . . . 24

13 Estimation of Heterogeneous PSVAR with Annual Data . . . . . . . . . . . . . 26

14 Estimation of Local Projections with Annual Data . . . . . . . . . . . . . . 28

\section{List of Tables}


1 Local Projections with Controls for Main Determinants of Y, PC, and PI with Annual Data $(\mathrm{OLS} \mathrm{FE})$. . . . . . . . . . . . . . . . . . . . . . 22

2 Local Projections at $h=4$ with Controls for General Uncertainty, Activity, and

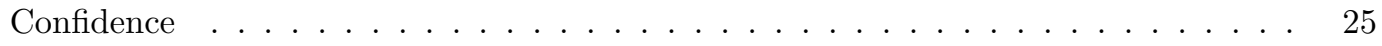

3 Local Projections with Controls for Main Determinants of Y, PC, and PI with An-

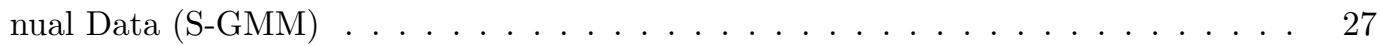

A.1 EPU Sample . . . . . . . . . . . . . . . . . . . . . . . . . . . . . . . . . . . . . . . . . . . . . . . . . . .

B.1 Data Sources . . . . . . . . . . . . . . . . . . . . . . . 32

B.2 List of Countries by Region . . . . . . . . . . . . . . . . . . . . . . . . 33 


\section{Introduction}

Since the outbreak of the Global Financial Crisis (GFC) in 2008, some events in key advanced and emerging economies contributed to a notable increase in economic policy uncertainty (EPU). In the United States (US), for example, discussions over the debt ceiling, threats of trade agreement annulments and re-negotiations, and the possibility of a fiscal expansion financed by changes to the tax system made policies harder to predict and resulted in repercussions for partner countries. In Europe, Brexit negotiations, fiscal challenges, and major elections in some countries had similar effects. In China, the leadership transition and currency adjustments had local effects, but also generated global spillovers. In some instances, regional and global events - rather than countryspecific ones - marked steep increases in global uncertainty, as in the case of the Arab spring and the immigration crisis in Europe, among others.

High levels of EPU revamped the debate about its impact on economic activity. While EPU has commonly a negative connotation, its sole meaning refers to uncertainty surrounding future policy, which does not necessarily imply a higher probability of implementing a policy that yields a worse outcome. Rather, a higher EPU just reflects that future shocks have a wider probability distribution (or even an unknown one), which includes shocks that would lead to better outcomes. Given these considerations, a higher EPU is not necessarily bad news, but the existing evidence points to the fact that economic agents dislike EPU and tend to react by re-weighting probabilities toward unfavorable events, in essence confounding certain for good and uncertain for bad and taking a "wait-and-see" approach. With increasingly stronger economic, financial, and political ties among countries, economic agents have reasons to be vigilant not only of domestic EPU, but of EPU abroad too.

In this paper, we examine how EPU originating abroad affects domestic economic activity. First, using the heterogeneous structural panel vector autoregression (PSVAR) framework by Pedroni (2013), we estimate the impact of EPU shocks on real growth in output, private consumption, and private investment, disentangling spillovers and domestic effects. Second, using the local projections method proposed by Jordà (2005), we focus on spillovers from a few large economies (US, Europe, and China) to macroeconomic aggregates in the rest of the world. We also analyze regional patterns and control for the main determinants of economic activity as well as other types of uncertainty.

The theoretical literature offers two contrasting views to explain the relationship between broadlydefined uncertainty and economic activity. On the one hand, the "real option" theory brought forward by Bernanke (1983), Brennan and Schwartz (1985), Dixit and Pindyck (1994), and McDonald and Siegel (1986) suggests that when irreversibility is high, investment has a real option value which tends to be higher during uncertain times. Private agents may therefore be reluctant to invest, hire, or purchase durable goods during periods of elevated uncertainty, leading to a decrease in economic activity. Similarly, the "risk aversion" theory proposed by Christiano et al. (2007), Arellano et al. (2010), and Gilchrist et al. (2014) posits that when uncertainty picks up, risk-averse agents demand to be compensated for taking on more risk. This increases risk premia and borrowing costs, and therefore reduces growth. On the other hand, two other theories postulate that uncertainty shocks have expansionary effects. The so-called "growth option" theory, following the work of Paddock et al. (1988) and Bar-Ilan and Strange (1996), argues that uncertainty can have a positive effect on investment by increasing the potential gains of a given project. The "Oi-Hartman-Abel" theory, based on the work by Oi (1961), Hartman (1972), and Abel (1983), highlights that firms' flexibility to alter their production volumes based on the uncertainty of output prices can have expansionary effects on growth. A more recent literature focuses specifically 
on EPU and proposes theoretical models predicting a contractionary impact of EPU on macroeconomic aggregates. In particular, the work by Rodrik (1991), Hassett and Metcalf (1999), Born and Pfeifer (2014), and Fernández-Villaverde et al. (2015) implies that EPU acts as a tax on macroeconomic aggregates, inducing adverse effects on economic activity.

As already noted, the empirical evidence supports these contractionary predictions, finding that domestic uncertainty reduces output (Ramey and Ramey, 1994; Baker and Bloom, 2013; Baker et al., 2016), consumption (Romer, 1990), investment (Leahy and Whited, 1996; Bloom et al., 2007; Gulen and Ion, 2015; Baker et al., 2016), hiring (ibid.), and trade (Novy and Taylor, 2014). Our paper belongs to a decisively slimmer body of recent empirical studies that looks at whether uncertainty shocks spill over to other economies. The majority of these studies focuses on shocks originating in the US. Mumtaz and Theodoridis (2015), for example, explore the spillover effects of an innovation to the volatility of a US GDP shock to the United Kingdom (UK). The study finds that the shock results in a drop in GDP and an increase in inflation in the UK, similar in magnitude to the response in the US. Similarly, Kamber et al. (2013) observe that a US uncertainty shock - proxied by the VIX - leads to a contraction in economic activity in a sample representative of the world economy. ${ }^{1}$ The results are robust to a factor-based uncertainty measure that combines information from the VIX, the Michigan Survey of Consumers, the US EPU index, and the Survey of Professional Forecasters. Carrière-Swallow and Céspedes (2013) confirm that a shock to the VIX affects investment and private consumption in a sample of 40 countries. Perhaps the studies most similar in spirit to ours are IMF (2013) and Colombo (2016), which analyze spillover effects from EPU. The analysis by the IMF (2013) suggests that EPU shocks in the US and in Europe suppress economic activity in a sample of 43 economies. Colombo (2016) shows that an unexpected increase in US EPU has spillover effects on macroeconomic aggregates in the Euro Area.

Our contribution to the literature analyzing spillovers from uncertainty is threefold. First, we disentangle the impact of EPU on the growth rate of output, private consumption, and private investment into spillovers and domestic effects, and study the relative importance of the former with respect to the latter in a sample of advanced and emerging economies. Second, we zoom in on the impact of EPU shocks originating in the US, Europe, and China on economic activity in the rest of the world. Third, we explore regional patterns of EPU spillovers from these countries or groups of countries. Our results suggest that country-specific shocks have a negative effect on domestic growth of output, private consumption, and private investment, but that spillovers are the principal driver of the negative impact of uncertainty on domestic macroeconomic aggregates. Moreover, increases in uncertainty in the US, Europe, and China produce slowdowns in economic activity in other countries up to one year after the shock. These effects are mostly felt in Europe and the Western Hemisphere. Our findings stand up to a number of robustness checks.

The remainder of the paper is organized as follows. Section 2 presents the data and stylized facts. Section 3 discusses the empirical strategy and the results. Section 4 presents the robustness tests. Section 5 concludes.

\footnotetext{
${ }^{1}$ The sample includes Australia, Canada, China, the Euro Area, Japan, and the UK.
} 


\section{Data and Stylized Facts}

Measuring uncertainty is a daunting task as it cannot be directly observed. Empirical studies employ a variety of observable proxies in its place. These include disagreement among professional forecasters over indicators such as GDP, inflation, and government purchases (Baker et al., 2016); measures based on forecasts errors of a wide set of macroeconomic indicators, including employment, GDP, inflation, and stock returns (Jurado et al., 2015; Rossi and Sekhposyan, 2015); and the dispersion in consumer and business confidence surveys (Bachmann et al., 2013). Another strand of the literature proxies uncertainty with the volatility of financial markets, in particular of stock market returns (Baker and Bloom, 2013; Carrière-Swallow and Céspedes, 2013; Kamber et al., 2013), bond market yields (Baker and Bloom, 2013), and exchange rates (ibid.). As an alternative to these macro-based measures, some empirical studies adopt micro-level measures based on the cross-sectional dispersion of firms' productivity growth (Bloom, 2014; Mongey and Williams, 2016).

Our aim, however, is to analyze the impact of uncertainty arising from the inability to predict future economic policies. The most prominent metric for this is the EPU index proposed by Baker et al. (2016). ${ }^{2}$ This index, here adopted, measures economic policy-related uncertainty based on newspaper frequency counts of keywords associated with EPU. ${ }^{3}$ Monthly data on EPU are available for 19 countries. For each of these countries, Baker et al. (ibid.) adjust the set of search terms to account for particularities of the country and its language. Moreover, the keywords are specified in the native language of the newspapers. ${ }^{4}$ The dataset is unbalanced, going back to 1985 for the countries with the maximum number of observations and to at least 2003 for the few countries with relatively short series; for the majority of the countries in the dataset, the series start in the first half of the 1990s. We construct a quarterly policy uncertainty measure by taking the simple average over the monthly EPU index. ${ }^{5}$ Appendix A provides a more detailed overview of the data on EPU.

To complete our dataset, we collect quarterly data on the three macroeconomic aggregates of interest to our study - real GDP (Y) growth, real private consumption (PC) growth, and real private investment (PI) growth - from the IMF World Economic Outlook (IMF-WEO) database as well as from the OECD National Accounts Database and the national accounts databases of specific countries to complement the IMF-WEO data. Finally, we add a set of macroeconomic and structural controls from the IMF Information Notice System, the IMF International Financial Statistics, the IMF-WEO, the OECD Main Economic Indicators, and the World Bank World Development Indicators. However, since the controls are mostly available only at annual frequency, we create an annual dataset too. Controls that were not available in real terms were deflated by the consumer price index. The full list of countries, controls, and data sources is available in Appendix B. We now document some key stylized facts of policy uncertainty. To appreciate the evolution of EPU across countries, Figure 1 presents a heatmap of EPU with coloring based on country-

\footnotetext{
${ }^{2}$ Other studies that develop policy uncertainty indexes based on the frequency of keywords in newspapers are limited in their country or topical coverage. Alexopoulos and Cohen (2015) focus only on the US and rely on one newspaper only while Husted et al. (2016) measure uncertainty exclusively about monetary policy.

${ }^{3}$ The index captures uncertainty regarding who will make the economic policy decision, when, and what the effect would be as a result of the action.

${ }^{4}$ Despite its widespread use in the literature, the EPU index remains potentially subject to measurement error. This may arise, for example, from unequal media coverage across journals and countries, subjective interpretation of the facts, and different writing styles.

${ }^{5}$ For the US, Baker et al. (2016) construct an additional index that combines uncertainty derived from newspaper coverage with a measure of the level of uncertainty stemming from federal tax code provisions, and a measure of dispersion of survey-based forecasts by The Philadelphia Federal Reserve. However, to ensure comparability across countries, we use the purely newspaper-based EPU index for the US.
} 
specific percentiles of the monthly EPU index series. Specifically, the color gradation from green to red reflects an EPU value ranging from low uncertainty (minimum to $10^{\text {th }}$ percentile of the country's EPU index) to high uncertainty ( $90^{\text {th }}$ percentile to maximum of the country's EPU index). The heatmap shows that EPU was high in some countries but not in others in the first part of the sample up to 2002, reflecting idiosyncratic events impacting uncertainty. Between 2003 and 2007, the coloring becomes more uniform, suggesting that EPU was low for most of the countries in the sample. With the outbreak of the GFC, many countries started to face higher EPU, but cross-country differences in coloring persist up to 2011, possibly reflecting different degrees of credibility of the commitments to take certain policy actions. With the intensification of the European debt crisis in 2011, another group of countries experienced high levels of EPU. Finally, after a temporary decline in some countries during 2014 to 2015, EPU increased uniformly again in 2016 and 2017. All in all, this heatmap provides some prima facie evidence that countries often tend to experience episodes of low and high EPU at the same time.

Figure 2 depicts the relationship between EPU and the macroeconomic aggregates of interest. In particular, it presents scatter plots, along with the linear regression lines, of EPU and real growth in GDP, private consumption, and private investment. The relationship is negative and significant for all three macroeconomic aggregates, with the correlation coefficient ranging from -0.2 for growth in private investment to -0.3 for growth in GDP and private consumption. This descriptive evidence is in line with the empirical literature finding a negative relationship between policy uncertainty and economic activity.

Finally, we take a look at whether this correlation varies across regions. ${ }^{6}$ As shown in Figure 3, EPU in the US is negatively correlated with real GDP growth in Asia and Pacific, Europe, and the Western Hemisphere but not in Africa or the Middle East and Central Asia. For growth in private consumption and investment, the negative correlation remains statistically significant only for Europe and the Western Hemisphere. Similarly, there is a negative and significant correlation between the European EPU index and macroeconomic aggregates in Asia and Pacific, Europe, and the Western Hemisphere. ${ }^{7}$ The negative correlation between EPU in China and real GDP growth is significant for all regions, except Asia and Pacific. This, however, is due to the presence of many small economies in the region, in which the economic cycle is strongly affected by natural disasters, climate change, and tourism. ${ }^{8}$ Chinese EPU, however, displays a negative association with investment in Asia and Pacific. These correlations provide preliminary evidence of possible spillovers of uncertainty and reveal a potential for heterogeneous dynamics across countries.

\footnotetext{
${ }^{6}$ See Appendix B for further details on country groups.

${ }^{7}$ European EPU is based on EPU in France, Italy, Germany, Spain, and the UK.

${ }^{8}$ Restricting the sample of Asia and Pacific economies to countries with at least three million people yields the expected negative and significant correlation coefficient between real GDP growth and EPU in China.
} 


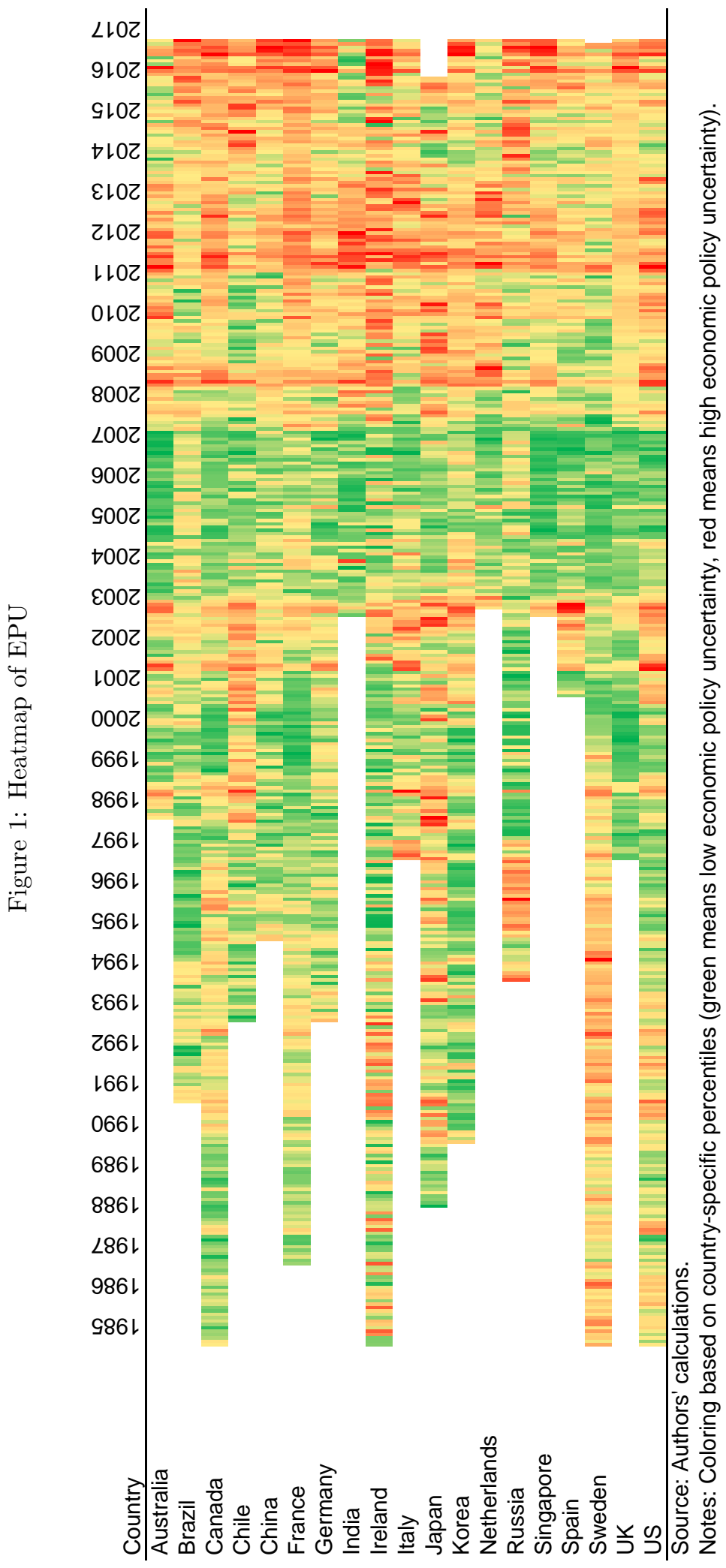


Figure 2: EPU and Macroeconomic Aggregates
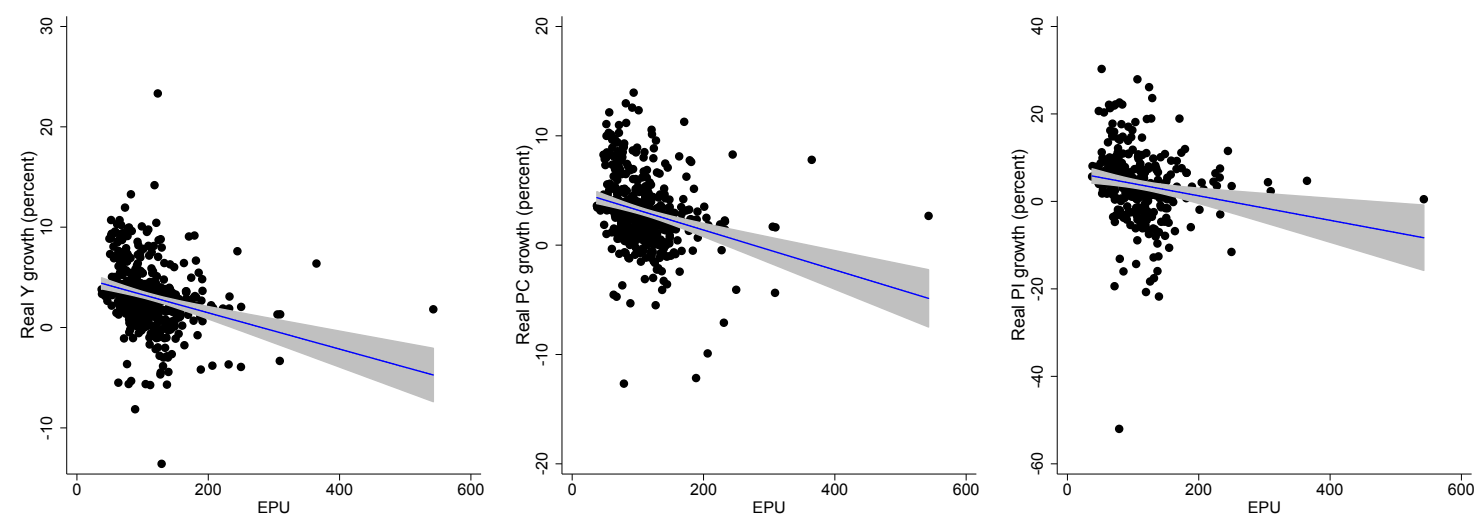

Source: Authors' calculations.

Notes: The blue lines represent the linear regression lines, the shaded areas represent the 95 percent confidence interval.

\section{Econometric Analysis}

We adopt two estimation approaches to study the spillovers of EPU on economic activity. We initially employ the heterogeneous PSVAR model proposed by Pedroni (2013). By allowing for complete heterogeneity across the countries in the panel, this method allows to decompose the response to a shock to EPU into a common component (i.e., spillover) and an idiosyncratic component (i.e., country-specific). The common component refers to the effect of EPU that originates in any other country in the sample and spills over to the domestic economy. ${ }^{9}$ The idiosyncratic component, on the other hand, refers to the effect of domestic EPU on the domestic economy. Subsequently, we rely on the flexibility of the local projections method developed by Jordà (2005) to extend our results in three directions. First, we study the impact of EPU shocks in the three largest economies or group of economies - Unites States, Europe, and China - on other countries' macroeconomic aggregates. Second, we explore regional heterogeneity of responses to EPU shocks. And third, we add a list of relevant controls to guard against possible omitted variable bias.

\subsection{Common and Idiosyncratic Effects of EPU}

\subsubsection{Heterogeneous PSVAR}

Let $y$ alternatively denote the growth rate of real GDP, real private consumption, or real private investment. We model the dynamic relationship between policy uncertainty and $y$ as a bivariate heterogeneous PSVAR:

$$
B_{i} z_{i, t}=A_{i}(L) z_{i, t-1}+\varepsilon_{i, t}
$$

\footnotetext{
${ }^{9}$ In the rest of the paper, we use the terms "spillovers" and "common effects" interchangeably.
} 
Figure 3: Correlations between EPU in the US, Europe, and China and Regional Macroeconomic Aggregates

(Percent)
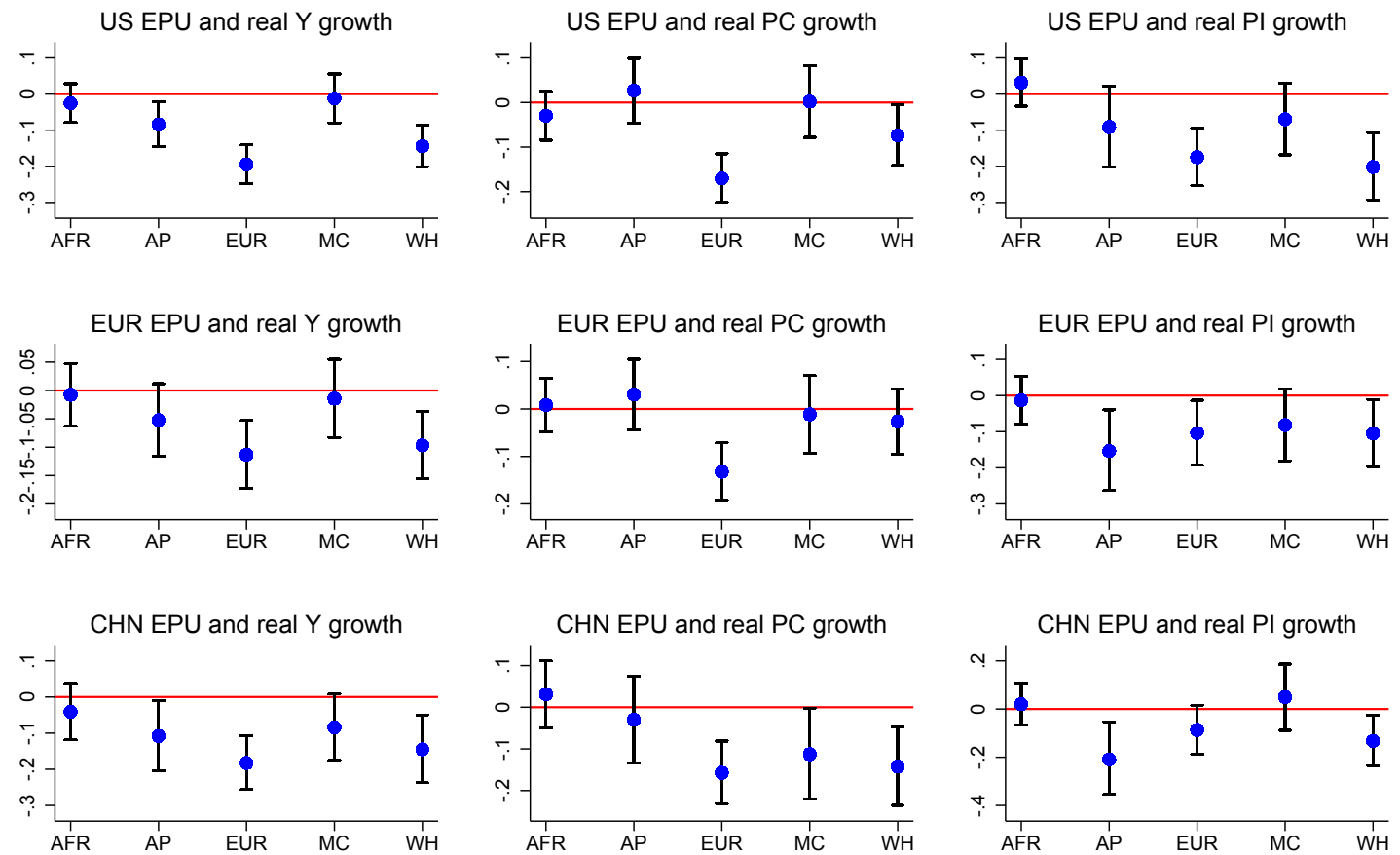

Source: Authors' calculations.

Notes: Correlations between the United States (Europe) [China] EPU and the macroeconomic aggregates exclude observations for the United States (Germany, Italy, France, Spain, and the United Kingdom) [China]. The bars represent the 95 percent confidence intervals. The following abbreviations apply: Africa (AFR), Asia and Pacific (AP), Europe (EUR), Middle East and Central Asia (MC), Western Hemisphere $(\mathrm{WH})$.

where $A_{i}(L)=\sum_{s=0}^{S_{i}} A_{i, s} L^{s}$ is a lag polynomial allowing for country-specific lag lengths, $i=$ $1, \ldots, N_{t}$, and $t=1, \ldots, T_{i}$. The $i$ and $t$ subscripts on the time and cross-section dimensions take into account that the panel may be unbalanced. Hence, for any $x$, the time average $\bar{x}_{i, .}=T_{i}^{-1} \sum_{t=1}^{T_{i}} x_{i, t}$. The vector $z_{i, t}=\left(\mathrm{EPU}_{i, t}-\overline{\mathrm{EPU}}_{i, .} \quad y_{i, t}-\bar{y}_{i, .}\right)^{\prime}$ contains the demeaned endogenous variables to account for country fixed effects. To disentangle common and idiosyncratic dynamics, which are akin to spillovers and country-specific effects, we can decompose each composite structural white noise shock in the vector $\varepsilon_{i t}$ into a common shock $\bar{\varepsilon}_{., t}$ and a country-specific idiosyncratic shock, $\tilde{\varepsilon}_{i, t}$ :

$$
\begin{aligned}
\varepsilon_{i, t}^{\mathrm{EPU}} & =\lambda_{i}^{\mathrm{EPU}} \bar{\varepsilon}_{\cdot, t}^{\mathrm{EPU}}+\tilde{\varepsilon}_{i, t}^{\mathrm{EPU}} \\
\varepsilon_{i, t}^{y} & =\lambda_{i}^{y} \bar{\varepsilon}_{\cdot, t}^{y}+\tilde{\varepsilon}_{i, t}^{y}
\end{aligned}
$$

with $\lambda_{i}^{\mathrm{EPU}}$ and $\lambda_{i}^{y}$ representing the country-specific loadings for the common structural shocks. For any $x$, the cross-sectional average is denoted as $x_{, t}=N_{t}^{-1} \sum_{i=1}^{N_{t}} x_{i, t}$.

To obtain the structural residuals and responses, we estimate a set of $N+1$ reduced-form VARs; 
one for each country $i$ and one for the cross-section average:

$$
\begin{aligned}
z_{1, t} & =B_{1}^{-1} A_{1}(L) z_{1, t-1}+u_{1, t} \\
& \vdots \\
z_{N, t} & =B_{N}^{-1} A_{N}(L) z_{N, t-1}+u_{N, t} \\
\bar{z}_{, t} & =\bar{B}^{-1} \bar{A}(L) \bar{z}_{, t-1}+\bar{u}_{., t}
\end{aligned}
$$

We recover the structural composite and common uncertainty shocks from the reduced-form residuals, $u_{i, t}=B_{i}^{-1} \varepsilon_{i, t}$ and $\bar{u}_{., t}=\bar{B}_{i}^{-1} \bar{\varepsilon}_{,, t}$. In line with the literature (Bloom, 2009; Carrière-Swallow and Céspedes, 2013), we rely on recursive restrictions assuming that uncertainty is predetermined with respect to the macroeconomic aggregates in our heterogeneous PSVAR.

Next, we construct the loading matrix for the common factors, $\Lambda_{i}$ from sample correlations between the structural residuals for each country $i:{ }^{10}$

$$
\Lambda_{i}=\left[\begin{array}{cc}
\rho\left(\varepsilon_{i, t}^{\mathrm{EPU}}, \bar{\varepsilon}_{, t}^{\mathrm{EPU}}\right) & 0 \\
0 & \rho\left(\varepsilon_{i, t}^{y},,^{y}, t\right)
\end{array}\right]
$$

We then obtain the common and idiosyncratic impulse responses, $\bar{A}_{i}(L)$ and $\tilde{A}_{i} L$, respectively, by combining the composite impulse responses to structural shocks, $A_{i}(L)$, with the loading matrices, $\Lambda_{i}$, for each country $i$ :

$$
A_{i}(L)=\Lambda_{i} A_{i}(L)+\left(I-\Lambda_{i} \Lambda_{i}^{\prime}\right) A_{i}(L)
$$

where $\Lambda_{i} A_{i}(L) \equiv \bar{A}_{i}(L)$ and $\left(I-\Lambda_{i} \Lambda_{i}^{\prime}\right) A_{i}(L) \equiv \tilde{A}_{i}(L)$. In line with Pedroni (2013), we re-scale the size of the structural idiosyncratic shocks such that all impulse responses can be interpreted as responses to unit shocks.

Finally, we compute descriptive statistics for the cross-sectional distribution of the composite response, $A_{i}(L)$, including the median, mean, and interquartile ranges, to present representative impulse responses for the heterogeneous dynamics in our sample, and we compute bootstrapped standards errors for the median response with 500 repetitions.

\subsubsection{Estimation Results}

Figure 4 presents the median, the average, and the $25^{\text {th }}$ and $75^{\text {th }}$ percentile composite responses of economic activity to an increase in EPU for the sample of 19 advanced and emerging market economies for which the EPU index is available. ${ }^{11}$ The initial response of real GDP growth to an

\footnotetext{
${ }^{10}$ The sample correlation between $\varepsilon_{i, t}$ and $\bar{\varepsilon}_{., t}$ corresponds to OLS estimates of $\Lambda_{i}$ in equation (2) since the variances of $\varepsilon_{i, t}$ and $\bar{\varepsilon}_{., t}$ have been normalized to unity (Pedroni, 2013).

${ }^{11}$ We ensure that the data on EPU and the year-on-year growth rates of real GDP, private consumption, and private investment are stationary.
} 
uncertainty shock is negative for all countries lying between the $25^{\text {th }}$ and $75^{\text {th }}$ percentile, with a similar response of both the median country and the average country. There is, nevertheless, some heterogeneity in the magnitude of the responses. The decline in real GDP growth in the third quarter after the shock is more than three times as large for the $25^{\text {th }}$ percentile than it is for the $75^{\text {th }}$ percentile. The median impact reaches the trough one quarter after the shock and dies out during the second year. The response of real private consumption growth to an increase in EPU is based on a sample of 15 countries and shows more heterogeneity, possibly reflecting different shares of purchases of durable goods across countries. While the median and the average responses reach their troughs during the first year - two and four quarters after the shock, respectively - the average response displays more persistence, suggesting that in some countries the effect takes longer to fade away. Also, for about 25 percent of the sample the negative effect is small, as shown by the $75^{\text {th }}$ percentile. Heterogeneity is even larger in the case of real private investment growth, where the sample is limited to 8 countries. The effect for the $25^{\text {th }}$ percentile is about six times larger than for the $75^{\text {th }}$ percentile. The negative effect is slightly more accentuated and persistent for the average country compared to the median one, even though both reach their troughs during the first year, respectively two and three quarters after the shock.

Figure 4: IRF Distribution from Heterogeneous PSVAR

(Percent)
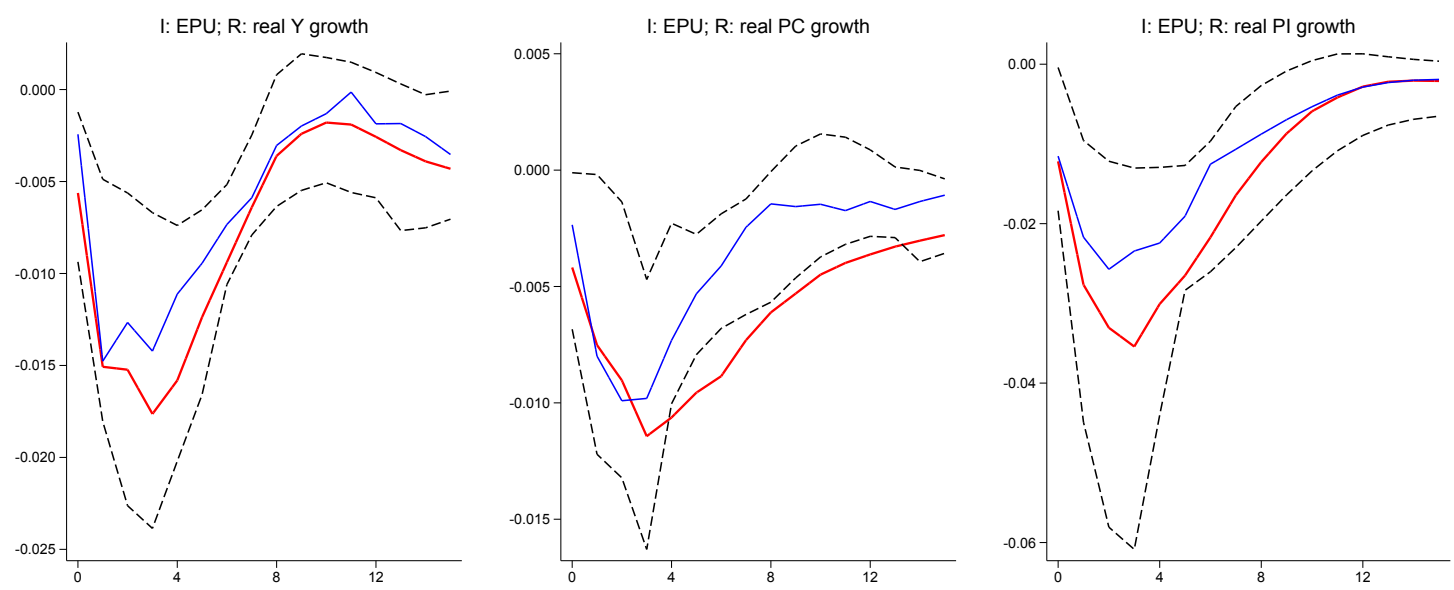

Source: Authors' calculations.

Notes: The blue (red) line represents median (average) effect, the dashed black lines represent the $25^{\text {th }}$ and $75^{\text {th }}$ percentiles.

Next, we assess the statistical significance of the composite median responses to an uncertainty shock. Figure 5 shows the median responses for the growth rates of real GDP, real private consumption, and real private investment together with the bootstrapped 95 percent confidence intervals. The response of real GDP growth is statistically significant up to three years after the shock. At its trough one quarter after the shock, a ten-unit increase in EPU is associated with a $0.1 \mathrm{pp}$ decline in real GDP growth. The median response of real private consumption growth is also statistically different from zero, and remains so up to two years after the shock. In this case, a tenunit increase in EPU is associated with a 0.1pp fall in private consumption growth two quarters after the shock. The response of real private investment growth loses its significance during the fourth year after the shock. However, the magnitude at the trough is considerably larger than for real GDP growth and real private consumption growth. Specifically, a ten-unit increase in EPU is associated with a $0.3 p p$ decline in real investment growth two quarters after the shock. 
Figure 5: Bootstrap of Heterogeneous PSVAR

(Percent)
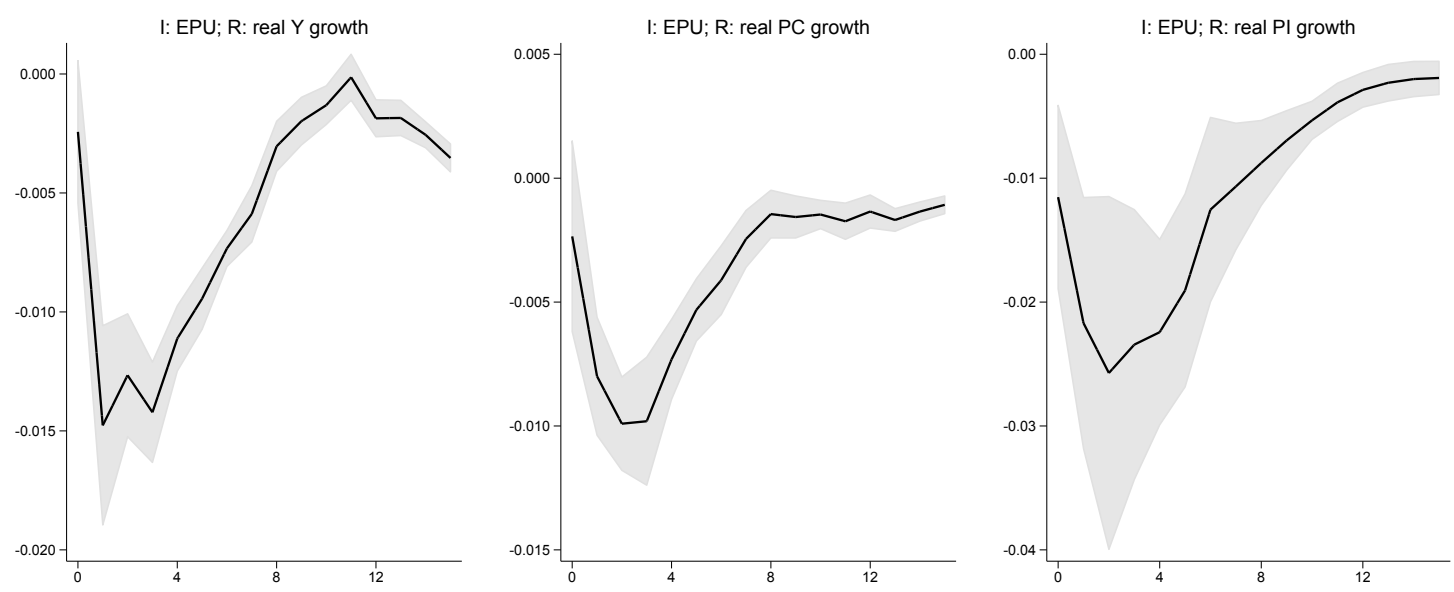

Source: Authors' calculations.

Notes: The black line represents the median effect, the shaded area represent the 95 percent confidence interval calculated from a resampling simulation with 100 repetitions.

The decomposition of the composite median impulse response into the response to a common shock and the response to an idiosyncratic shock suggests that common shocks are more sizable. Figure 6 shows that a common uncertainty shock explains roughly two-thirds of the decline in GDP growth across all horizons. Common shocks are also more important than idiosyncratic shocks for private consumption and private investment growth. Hence, spillovers of policy uncertainty do impact economic activity, and to a larger extent than domestic shocks. ${ }^{12}$

\subsection{Spillovers of EPU from the US, Europe, and China}

\subsubsection{Local Projections}

We now turn to estimating the spillovers of EPU originating in the US, Europe, and China, on other economies' macroeconomic aggregates. The local projections method, similar to a classical VAR model, allows to recover the dynamics of the dependent variable after a shock. Local projections, however, have a number of advantages over the VAR models typically used in the literature. Specifically, the local projections method generates estimates that are less vulnerable to misspecification of the data generating process because the impulse response is estimated separately for each horizon. Also, it allows controlling for a relatively large set of variables, which would be impractical in a regular VAR setting. Finally, it can easily accommodate non-linear specifications, which we use to uncover regional patterns.

Our baseline panel specification is:

\footnotetext{
${ }^{12}$ The finding that spillovers are quantitatively important is in line with other studies, which show that spillovers from general uncertainty in the US are large and similar in magnitude to domestic effects (among others, Colombo, 2016; Kamber et al., 2013; Mumtaz and Theodoridis, 2015).
} 
Figure 6: Median Effect Decomposition from Heterogeneous PSVAR

(Percent)
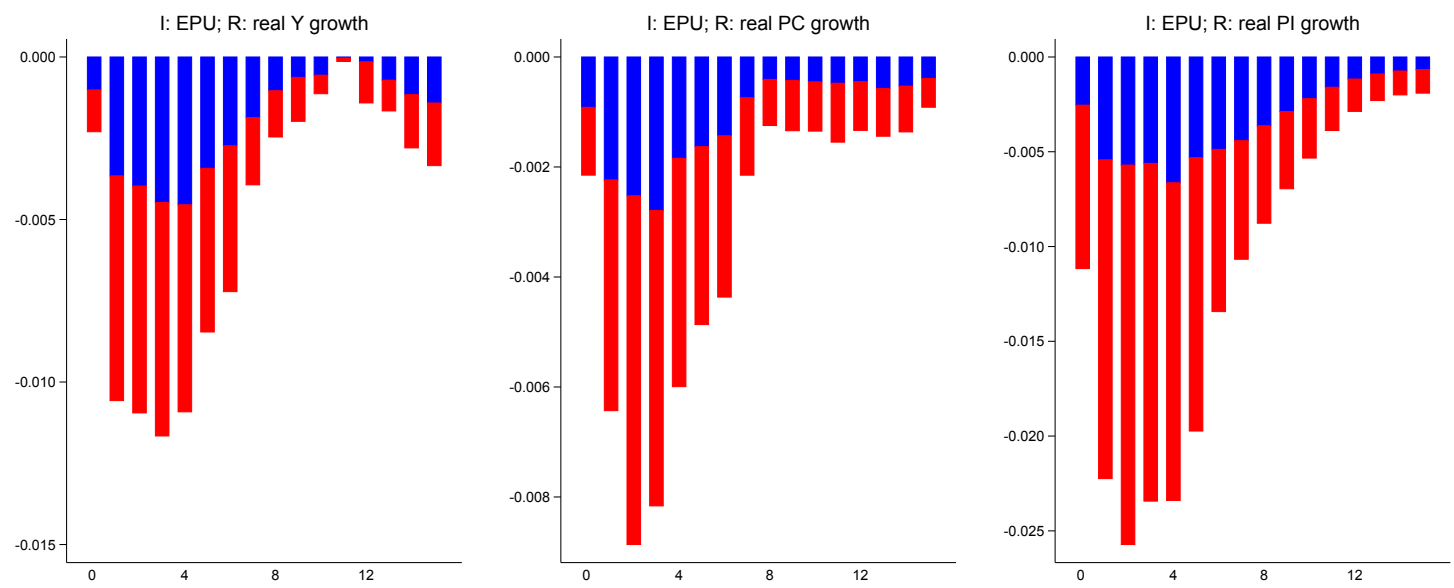

Source: Authors' calculations.
Notes: Blue (red) bars represent median responses to idiosyncratic (common) shocks.

$$
y_{i, t+h}=\alpha_{h}+\sum_{k=0}^{m} \beta_{k, h} \mathrm{EPU}_{t-k}^{j}+u_{i}+v_{i, t+h}
$$

where $y$ is, alternatively, real GDP growth, real private consumption growth, or real private investment growth; $j=$ China, Europe, US, is the superscript for the country where the EPU shock originates; $i=1, \ldots, N_{t}$, is the subscript for the country to which the effect is spilled over; $t=1, \ldots, T_{i}$, is the time subscript; $k=0, \ldots, m$, are the lags of EPU; $h=1, \ldots, H$, is the horizon of the local projection; $u_{i}$ denotes country fixed effects; and $v$ is an error term. ${ }^{13}$

The IRFs are then constructed by plotting the coefficient $\beta_{0, h}$ for the set of $H$ regressions. Given the high degree of collinearity between policy uncertainty in the US, Europe, and China, we estimate the spillover effect separately for each of them, in line with IMF (2013). ${ }^{14}$ We ensure exogeneity of the uncertainty shock by excluding the observations for the countries in which the shock originates from our sample. For example, to estimate the spillover effect of an EPU shock in the US, we compute the IRF for the sample of countries excluding the US itself.

Subsequently, to investigate regional differences in the response to an uncertainty shock, we extend the baseline specification to a nonlinear one as follows:

\footnotetext{
${ }^{13}$ This specification is similar to IMF (2013). Similarly, we do not include year dummies because the variable of interest, $\mathrm{EPU}^{j}$, is common across all countries.

${ }^{14}$ One could argue that a better measure of idiosyncratic shocks in the US, Europe, and China is the orthogonal component of each of these countries' EPU series with respect to the other countries' ones. This approach, however, would greatly reduce the variation in the series related to idiosyncratic events occurring during the same year. For example, the Eurozone debt crisis and the US debt ceiling discussion, as well as the China leadership transition, took place in 2011; the European immigration crisis and the Chinese equity sell-off happened in 2015; Brexit and the US presidential election occurred in 2016. Despite this drawback, when we use the orthogonal components of the series rather than the original ones, we find that the results for shocks to EPU in the US and China are broadly consistent, and that the results for shocks to European EPU are mixed.
} 


$$
y_{i, t+h}=\alpha_{h}+\sum_{k=0}^{m} \beta_{k, h} \mathrm{EPU}_{t-k}^{j}+\sum_{k=0}^{m} \gamma_{k, h} \mathrm{EPU}_{t-k}^{j} D^{r}+u_{i}+v_{i, t+h}
$$

where $r$ indicates the regions in our sample. In this case, however, the specification is estimated with annual data to have the largest regional coverage. We estimate this specification separately for each region and compare the size of the spillover to region $r$ (which is the sum of $\beta_{0, h}$ and $\left.\gamma_{0, h}\right)$ to the spillover to the rest of the world (that is equal to $\beta_{0, h}$ ).

Finally, we include a set of relevant controls to ensure that the estimated impulse response functions capture the effect of EPU spillovers rather than the effect of other determinants of economic activity:

$$
y_{i, t+h}=\alpha_{h}+\sum_{k=0}^{m} \beta_{k, h} \mathrm{EPU}_{t-k}^{j}+\delta_{h} \mathrm{X}_{i, t-1}+\theta_{h} \mathrm{Z}_{i, t}+u_{i}+v_{i, t+h}
$$

where $X$ is a vector of potentially endogenous controls lagged for one period to address endogeneity concerns, and $Z$ is a vector of exogenous controls.

\subsubsection{Estimation Results}

We start by presenting the results of the local projections estimating spillovers from EPU in the US, Europe, and China using quarterly data. We compute the response to a shock to EPU for the sample that excludes the countries in which the shock originates. To allow for comparability with the PSVAR, we first estimate the specification in equation (6) without controls, that is, excluding the vectors $X$ and $Z$. Figure 7 displays the IRFs for growth in real GDP, real private consumption, and real private investment, along with 95 percent confidence intervals.

The results suggest that an increase in US policy uncertainty temporarily reduces real GDP growth in a sample of 64 other economies. The response is largest in magnitude three quarters after the shock, when an increase in the EPU index by ten units is associated with a decline in real GDP growth by approximately $0.2 \mathrm{pp}$. The effect dies out during the third year after the shock. To give a better sense of the magnitude of the effect, one could rely on the increase in the annual average of the EPU index in 2007 and 2008 of 59 units as a reference point. ${ }^{15}$ An increase in the US EPU of this magnitude is associated with a decline of 1.4pp in GDP growth, on average, in other economies. The IRFs also display significant declines in the growth rates of real private consumption (in a sample of 37 economies) and real private investment (in a sample of 13 economies), which reach their troughs four quarters after the shock and fade away during the third year after the shock. While the magnitude of the response of private consumption growth is slightly smaller than the response of GDP, growth in private investment responds more strongly to a ten-unit increase in US EPU, with an effect of roughly $0.6 \mathrm{pp}$ at the trough.

The negative effect of an increase in European and Chinese EPU on real GDP growth abroad lasts for about two years and displays the trough four quarters after the shock. Similarly, for private consumption and private investment, the effect reaches its trough three to four quarters after the

\footnotetext{
${ }^{15}$ We refer to the news-based US EPU index for comparability with the European and Chinese EPU indexes.
} 
shock and takes about two years to die out. In terms of magnitude, spillovers from Europe are similar to spillovers from China, and are smaller than the spillover effects from the US.

Figure 7: Spillovers from an EPU Shock in the US, Europe, and China

(Percent)
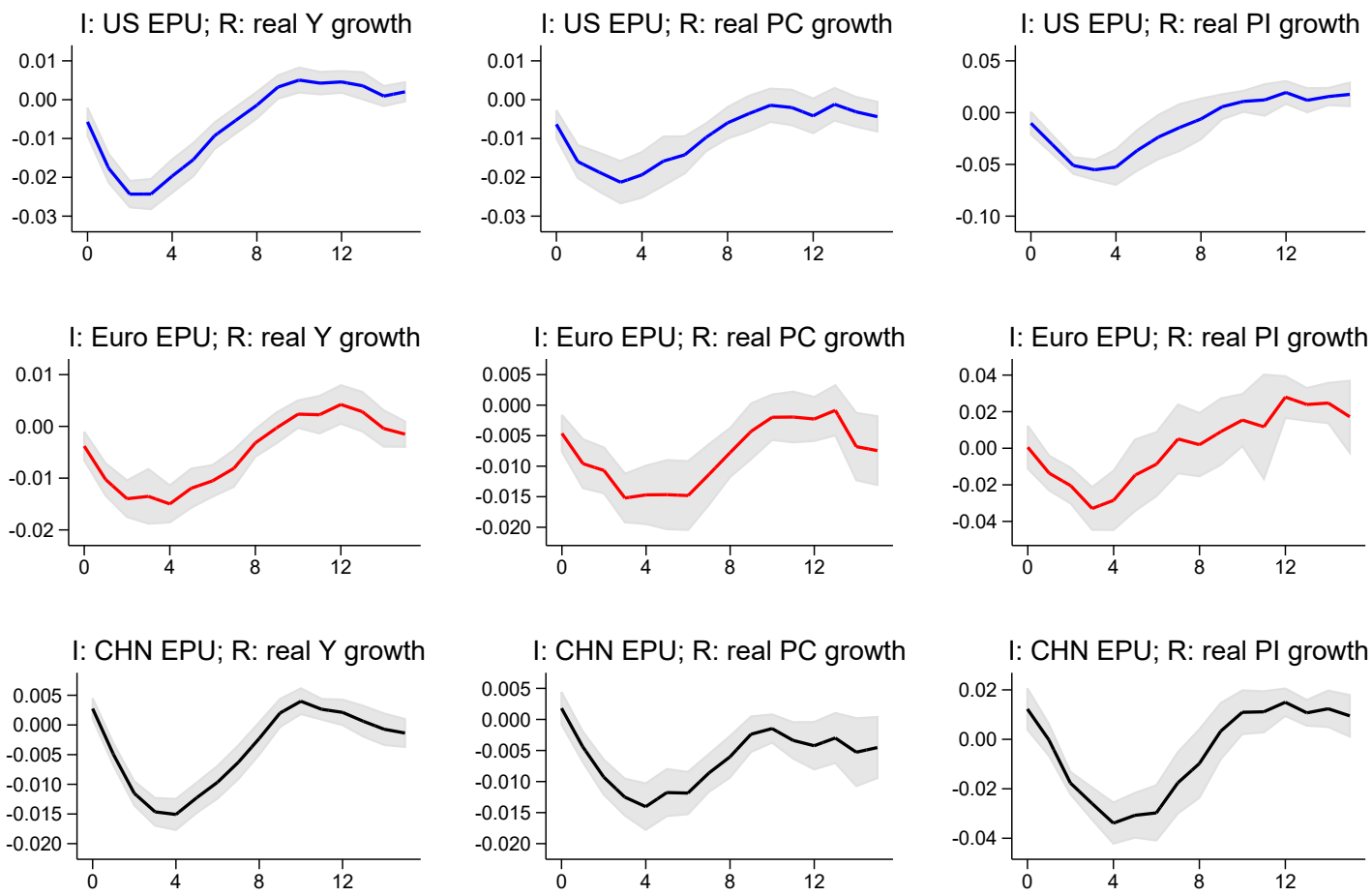

Source: Authors' calculations

Notes: IRFs for shocks to the United States (Europe) [China] EPU exclude the response of the United States (Germany, Italy, France, Spain, and the United Kingdom) [China]. The shaded areas represent the 95 percent confidence intervals.

Next, switching to the annual dataset, we explore regional heterogeneity in spillover effects from EPU. More precisely, we compute IRFs for each region and compare those responses to the rest of the world. As discussed in Section 3.2.1, we rely on annual data to have the broadest regional coverage. Figure 8 presents IRFs for spillovers from the US to the five regions in our sample. The areas in between the red dashed lines and the areas shaded in blue represent the 95 percent confidence intervals for the region of interest and the rest of the world, respectively. The IRFs reveal large regional differences in response to policy uncertainty shocks.

Spillovers from policy uncertainty in the US are significant for Asia and Pacific, Europe, and the Western Hemisphere. Compared to the rest of the world, the spillover effects from US policy uncertainty are larger and more statistically significant for Europe and the Western Hemisphere. These findings make sense intuitively since they support the idea that spillovers occur between economies that are more closely integrated. Spillovers from policy uncertainty in Europe and China also reduce GDP growth in Asia and Pacific, other European economies, and the Western Hemisphere. Figure 9 illustrates that an increase in the European EPU index does not, however, affect consumption and investment growth outside Europe. This stands in contrast to China. As shown in Figure 10, a shock to EPU in China is associated with a negative response in GDP, as well as 
private consumption and investment, in Europe and the Western Hemisphere. The reduction in GDP growth in Asia and Pacific in response to a Chinese EPU shock is only marginally significant, but as previously noted, this is likely due to the presence of many small economies in the region, in which economic activity is strongly affected by natural disasters, climate change, and tourism. Also, this outcome may be explained by the importance of trade in the transmission of EPU shocks. While China does trade with the other countries in the region, the US and Europe are its main trading partners. ${ }^{16}$ Overall, the responses to European and Chinese policy uncertainty are smaller than the responses to US policy uncertainty.

Finally, using the annual dataset, we include a set of controls for the determinants of economic activity in our local projections to verify that our results do not suffer from omitted variable bias. Even in this case, however, we rely on annual data as most of the controls are available at that frequency. The choice of the control variables is guided by the literature on growth and consumption/saving theory, previous empirical research, and data availability. ${ }^{17}$ To address concerns about reverse causality between macroeconomic aggregates and some of the controls, we lag potentially endogenous controls by one year. Table 1 presents the results for each horizon considered in the IRFs. The results are consistent both in terms of timing and magnitude with the results reported without the controls. ${ }^{18}$

\footnotetext{
${ }^{16}$ See, for example, Choi (2017) on the importance of the trade channel in the transmission of EPU shocks.

${ }^{17}$ For a more comprehensive discussion on the choice of controls and their link with key macro aggregates, see Grigoli et al. (2014).

${ }^{18}$ The low $R^{2}$ can be explained by the heterogeneity of countries included in our sample. When we restrict the sample to advanced economies, the $R^{2}$ increases and the coefficients of interest remain similar.
} 


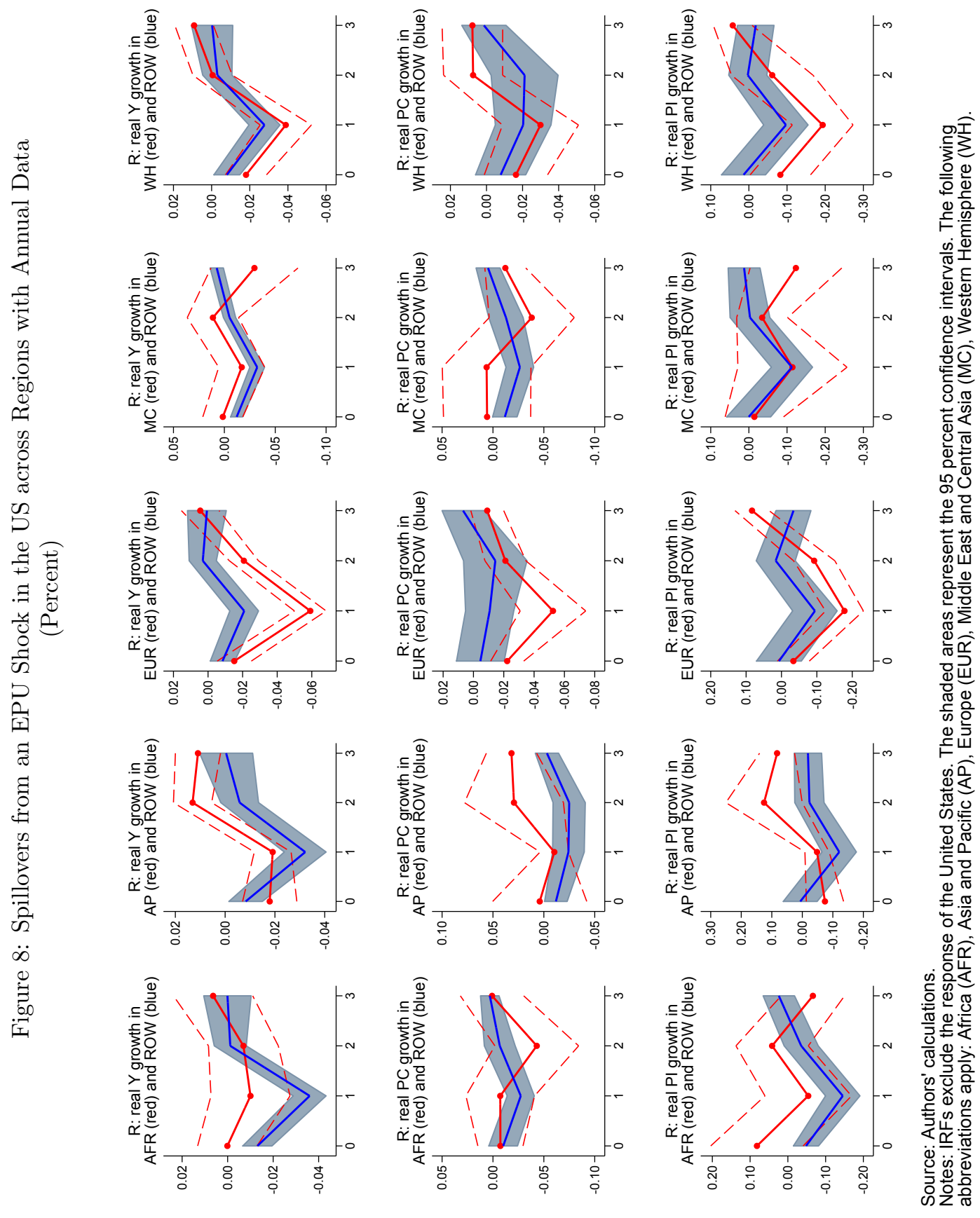




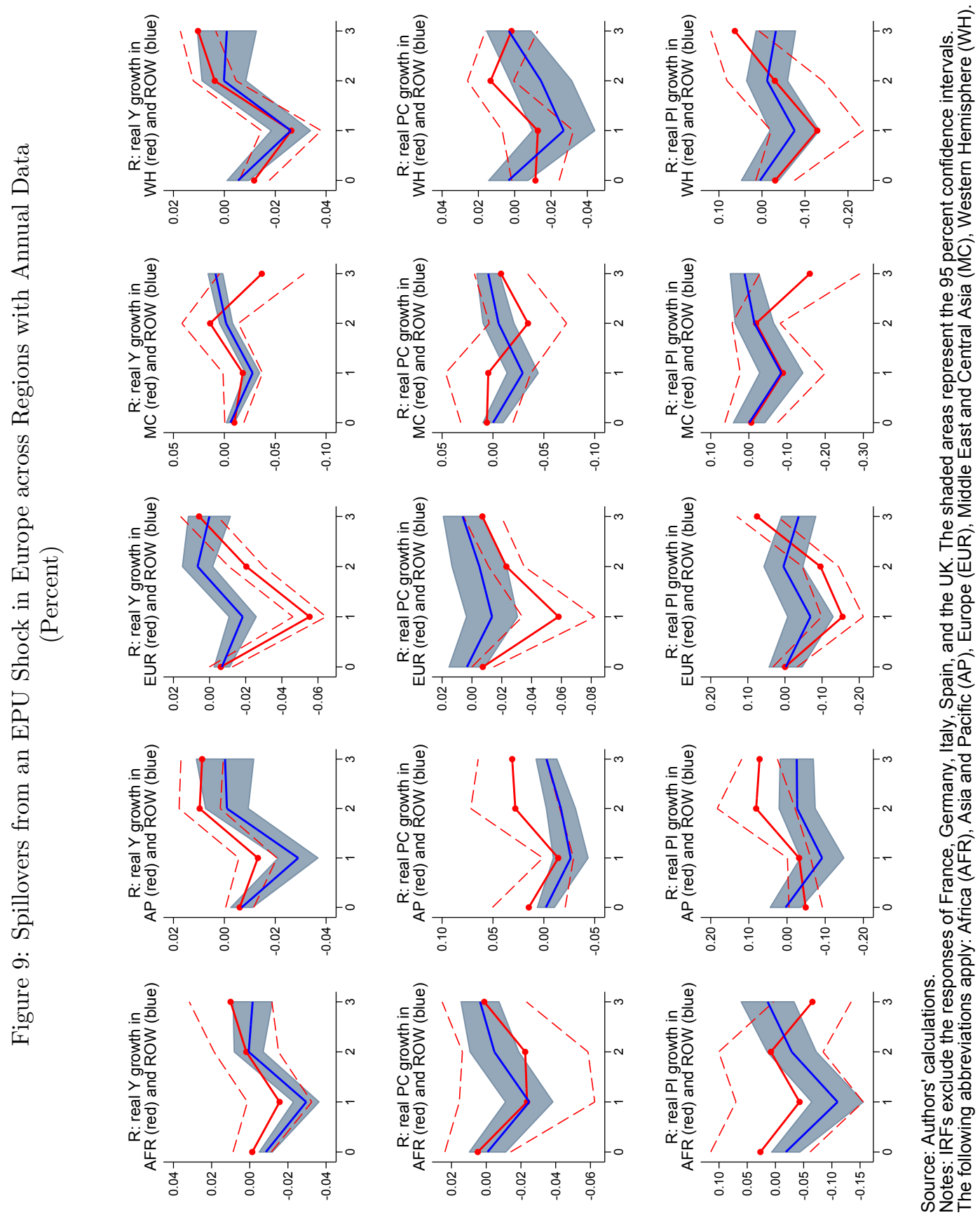




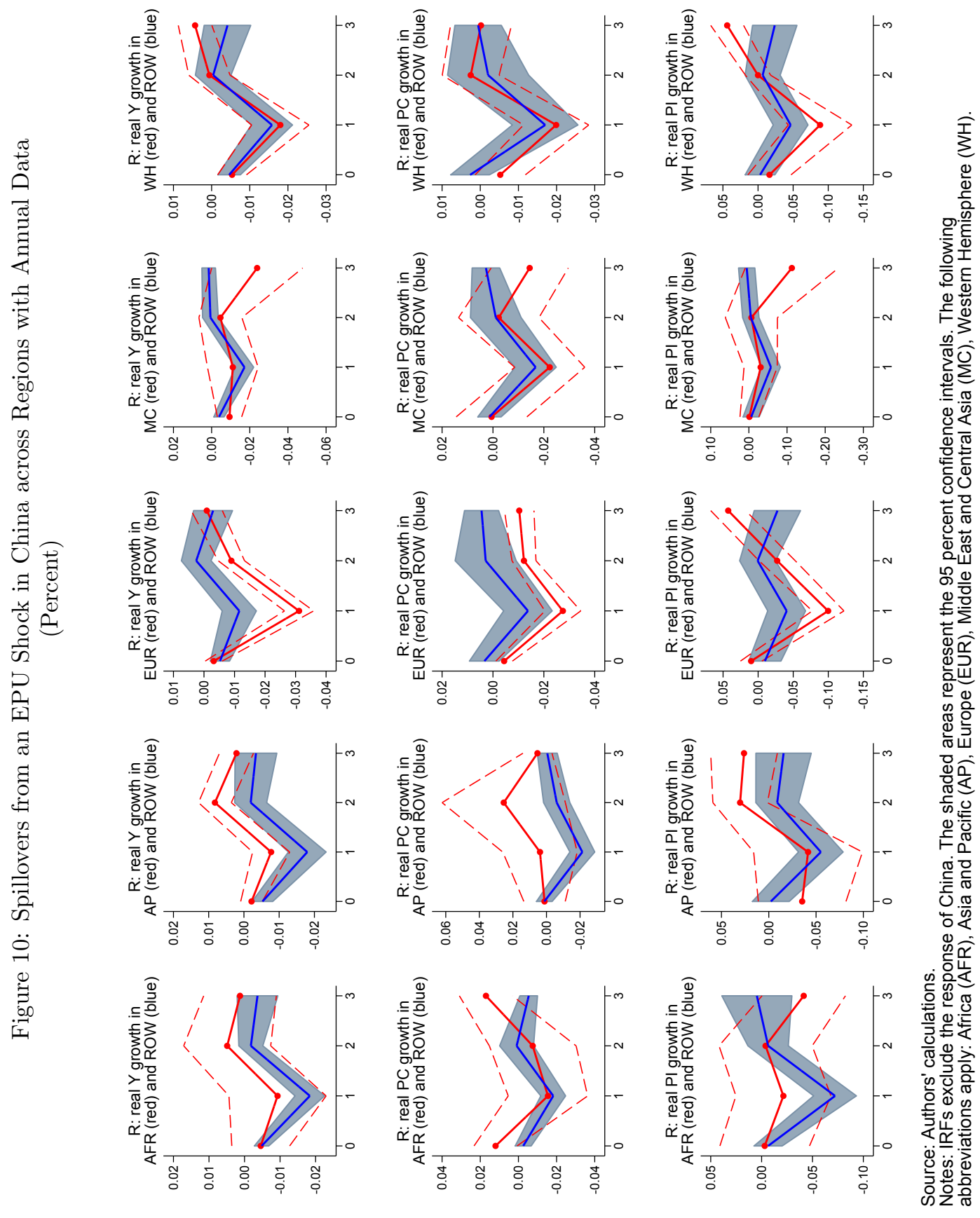




\section{Robustness}

\subsection{Heterogeneous PSVAR}

We assess the robustness of the results from the PSVAR with several tests. First, we test whether the response of macroeconomic aggregates remains negative and significant when we account for changes in general uncertainty (proxied by GDP forecast dispersion and stock market volatility), changes in economic activity (proxied by stock market returns), and confidence in the economy (proxied by consumer confidence and business confidence). Figure 11 presents the IRFs for the growth rates of output, private consumption, and private investment when a third variable is added to the PSVAR specification. The median responses to EPU uncertainty shocks remain negative and significant for all aggregates when controlling for these factors. In particular, the responses of real GDP growth and real consumption growth are remarkably similar, both in terms of size and shape. In the case of private investment growth, the size of the response at the trough is halved when we control for GDP forecast dispersion and consumer confidence. Accounting for confidence levels in the economy does not strongly affect our results.

Second, we invert the recursive ordering of the endogenous regressors in the baseline specification to have the measure of economic activity - which is, alternatively, growth in real GDP, real private consumption, or real private investment-before EPU. This implies that the response of economic activity is restricted to zero upon impact. Figure 12 illustrates that, under the alternative ordering, the response to an EPU shock remains negative and significant and presents a similar shape to the one under the baseline ordering. In all cases, the size of the negative effect at the through is smaller under the alternative ordering, but quickly becomes of similar magnitude.

Third, we run all the estimations restricting the sample to either the pre-GFC period or the postGFC period. Despite the reduced sample size, the results are remarkably similar to the ones with the unrestricted sample, even though the confidence intervals are comparatively larger. Also, additional tests show that the results are robust to different definitions of EPU shocks. In particular, we redefine the EPU variable, alternatively, as a dummy that takes the value one when the cyclical component of EPU extracted from a Hodrick-Prescott filter exceeds its mean by more than 1.65 standard deviations, ${ }^{19}$ and as the percent deviation of EPU from its trend. Using these alternative definitions does not affect our results. Furthermore, allowing for more lags of the endogenous variables in the PSVAR does not affect our findings. ${ }^{20}$

Finally, we estimate the PSVAR with annual data, where we limit the sample to countries with at least 20 years of data. Figure 13 shows the impact of an EPU shock on annual growth rates for the three measures of economic activity. Consistent with the baseline results, the response at the trough is negative for all countries between the $25^{\text {th }}$ and $75^{\text {th }}$ percentiles (top panels). As with quarterly data, the response for the median country is statistically significant over a period of two to three years. However, it reaches the trough one year after the shock, which is slightly after than with annual data, and its magnitude is somewhat larger (middle panels). The decomposition of the composite shocks suggests that the spillovers from a common shock are larger than the the effects stemming from domestic EPU, supporting our baseline results (bottom panels).

\footnotetext{
${ }^{19}$ This measure is equivalent to the one used in IMF (2013).

${ }^{20}$ The results using restricted samples, alternative measures of EPU, and different lag structures are available upon request.
} 
Table 1: Local Projections with Controls for Main Determinants of Y, PC, and PI with Annual Data (OLS FE)

\begin{tabular}{|c|c|c|c|c|c|c|c|c|c|}
\hline & $\begin{array}{c}(1) \\
\text { Dep: Y }\end{array}$ & $\begin{array}{c}(2) \\
\text { Dep: PC }\end{array}$ & $\begin{array}{c}(3) \\
\text { Dep PI }\end{array}$ & $\begin{array}{c}(4) \\
\text { Dep: Y }\end{array}$ & $\begin{array}{c}(5) \\
\text { Dep: PC }\end{array}$ & $\begin{array}{c}(6) \\
\text { Dep PI }\end{array}$ & $\begin{array}{c}(7) \\
\text { Dep: Y }\end{array}$ & $\begin{array}{c}\text { (8) } \\
\text { Dep: PC }\end{array}$ & $\begin{array}{c}(9) \\
\text { Dep PI }\end{array}$ \\
\hline \multicolumn{10}{|l|}{ Dependent variable at $h=0$} \\
\hline US EPU & $\begin{array}{c}-0.013^{* * *} \\
(0.003)\end{array}$ & $\begin{array}{c}-0.010 \\
(0.009)\end{array}$ & $\begin{array}{c}-0.021 \\
(0.028)\end{array}$ & & & & & & \\
\hline Lag US EPU & $\begin{array}{c}-0.017^{* * * *} \\
(0.004)\end{array}$ & $\begin{array}{c}-0.026^{* * *} * \\
(0.008)\end{array}$ & $\begin{array}{c}-0.088^{* * * *} \\
(0.025)\end{array}$ & & & & & & \\
\hline Europe EPU & & & & $\begin{array}{c}-0.014^{* * *} \\
(0.003)\end{array}$ & $\begin{array}{l}-0.006 \\
(0.012)\end{array}$ & $\begin{array}{c}-0.010 \\
(0.021)\end{array}$ & & & \\
\hline Lag Europe EPU & & & & $\begin{array}{c}-0.008^{* *} \\
(0.003)\end{array}$ & $\begin{array}{c}-0.025^{* *} \\
(0.010)\end{array}$ & $\begin{array}{c}-0.047^{* *} \\
(0.023)\end{array}$ & & & \\
\hline China EPU & & & & & & & $\begin{array}{c}-0.011^{* * * *} \\
(0.002)\end{array}$ & $\begin{array}{c}-0.009^{* *} \\
(0.004)\end{array}$ & $\begin{array}{l}-0.011 \\
(0.011)\end{array}$ \\
\hline Lag China EPU & & & & & & & $\begin{array}{c}-0.017^{* * * *} \\
(0.003)\end{array}$ & $\begin{array}{c}-0.029^{* * *} \\
(0.005)\end{array}$ & $\begin{array}{c}-0.054^{* * *} * \\
(0.012)\end{array}$ \\
\hline Ln real per capita GDP & $\begin{array}{c}0.751 \\
(1.107)\end{array}$ & $\begin{array}{c}-0.281 \\
(0.975)\end{array}$ & $\begin{array}{c}-5.676^{* * *} \\
(1.608)\end{array}$ & $\begin{array}{l}1.415 \\
(1.043)\end{array}$ & $\begin{array}{c}0.344 \\
(0.968)\end{array}$ & $\begin{array}{c}-4.022^{* *} \\
(1.756)\end{array}$ & $\begin{array}{c}1.267 \\
(1.205)\end{array}$ & $\begin{array}{c}0.118 \\
(1.404)\end{array}$ & $\begin{array}{l}-0.440 \\
(3.556)\end{array}$ \\
\hline ToT growth & $\begin{array}{c}0.035^{* * *} \\
(0.010)\end{array}$ & $\begin{array}{l}-0.007 \\
(0.043)\end{array}$ & $\begin{array}{l}-0.052 \\
(0.085)\end{array}$ & $\begin{array}{c}0.035^{* * * *} \\
(0.010)\end{array}$ & $\begin{array}{l}-0.011 \\
(0.043)\end{array}$ & $\begin{array}{l}-0.061 \\
(0.085)\end{array}$ & $\begin{array}{c}0.028^{* * *} \\
(0.011)\end{array}$ & $\begin{array}{c}-0.024 \\
(0.045)\end{array}$ & $\begin{array}{l}0.106^{*} \\
(0.064)\end{array}$ \\
\hline Real oil price & $\begin{array}{c}0.008 \\
(0.008)\end{array}$ & $\begin{array}{c}0.018 \\
(0.012)\end{array}$ & $\begin{array}{c}0.083^{* * * *} \\
(0.029)\end{array}$ & $\begin{array}{c}0.008 \\
(0.007)\end{array}$ & $\begin{array}{c}0.018 \\
(0.013)\end{array}$ & $\begin{array}{l}0.066^{* *} \\
(0.029)\end{array}$ & $\begin{array}{c}0.011 \\
(0.007)\end{array}$ & $\begin{array}{c}0.017 \\
(0.012)\end{array}$ & $\begin{array}{c}0.043 \\
(0.034)\end{array}$ \\
\hline Old-age dependency ratio & $\begin{array}{c}-0.259^{* * * *} \\
(0.092)\end{array}$ & $\begin{array}{c}-0.329^{* * *} \\
(0.125)\end{array}$ & & $\begin{array}{c}-0.241^{* *} \\
(0.120)\end{array}$ & $\begin{array}{l}-0.248 \\
(0.164)\end{array}$ & & $\begin{array}{l}-0.161 \\
(0.108)\end{array}$ & $\begin{array}{l}-0.123 \\
(0.148)\end{array}$ & \\
\hline Share of urban population & $\begin{array}{l}-0.027 \\
(0.054)\end{array}$ & $\begin{array}{c}0.031 \\
(0.103)\end{array}$ & & $\begin{array}{l}-0.007 \\
(0.051)\end{array}$ & $\begin{array}{c}0.090 \\
(0.104)\end{array}$ & & $\begin{array}{c}-0.010 \\
(0.052)\end{array}$ & $\begin{array}{c}0.105 \\
(0.121)\end{array}$ & \\
\hline Lag inflation & $\begin{array}{c}-0.022^{*} \\
(0.012)\end{array}$ & $\begin{array}{c}-0.093^{* * * *} \\
(0.025)\end{array}$ & $\begin{array}{c}0.002 \\
(0.003)\end{array}$ & $\begin{array}{c}-0.025^{*} \\
(0.012)\end{array}$ & $\begin{array}{c}-0.096^{* * * *} \\
(0.026)\end{array}$ & $\begin{array}{c}0.001 \\
(0.003)\end{array}$ & $\begin{array}{c}-0.034^{* * * *} \\
(0.012)\end{array}$ & $\begin{array}{c}-0.114^{* * * *} \\
(0.024)\end{array}$ & $\begin{array}{c}0.052 \\
(0.126)\end{array}$ \\
\hline Lag real appreciation & $\begin{array}{c}-0.003 \\
(0.008)\end{array}$ & $\begin{array}{c}0.005 \\
(0.017)\end{array}$ & $\begin{array}{l}-0.009 \\
(0.071)\end{array}$ & $\begin{array}{l}-0.002 \\
(0.009)\end{array}$ & $\begin{array}{c}0.003 \\
(0.017)\end{array}$ & $\begin{array}{c}-0.006 \\
(0.071)\end{array}$ & $\begin{array}{c}0.000 \\
(0.009)\end{array}$ & $\begin{array}{c}0.021 \\
(0.024)\end{array}$ & $\begin{array}{c}0.008 \\
(0.075)\end{array}$ \\
\hline Lag real interest rate & $\begin{array}{c}-0.068^{* *} \\
(0.034)\end{array}$ & $\begin{array}{l}-0.068 \\
(0.054)\end{array}$ & $\begin{array}{l}-0.116 \\
(0.114)\end{array}$ & $\begin{array}{c}-0.070^{* *} \\
(0.033)\end{array}$ & $\begin{array}{l}-0.078 \\
(0.054)\end{array}$ & $\begin{array}{l}-0.116 \\
(0.112)\end{array}$ & $\begin{array}{c}-0.109^{* * * *} \\
(0.035)\end{array}$ & $\begin{array}{l}-0.105^{*} \\
(0.058)\end{array}$ & $\begin{array}{l}-0.263 \\
(0.207)\end{array}$ \\
\hline Lag flow of private sector credit growth & $\begin{array}{c}-0.087^{* * *} \\
(0.033)\end{array}$ & $\begin{array}{l}-0.045 \\
(0.038)\end{array}$ & $\begin{array}{c}-0.365^{* * *} \\
(0.131)\end{array}$ & $\begin{array}{c}-0.090^{* * * *} \\
(0.033)\end{array}$ & $\begin{array}{l}-0.065 \\
(0.040)\end{array}$ & $\begin{array}{c}-0.360^{* * * *} \\
(0.130)\end{array}$ & $\begin{array}{c}-0.079^{* *} \\
(0.030)\end{array}$ & $\begin{array}{l}-0.040 \\
(0.037)\end{array}$ & $\begin{array}{c}-0.364^{* * * *} \\
(0.114)\end{array}$ \\
\hline Lag real govt. purchases growth & $\begin{array}{l}0.024^{* *} \\
(0.010)\end{array}$ & & & $\begin{array}{l}0.023^{* *} \\
(0.010)\end{array}$ & & & $\begin{array}{c}0.023^{* *} \\
(0.010)\end{array}$ & & \\
\hline Lag real govt. $\mathrm{C}$ growth & & $\begin{array}{c}-0.012 \\
(0.039)\end{array}$ & & & $\begin{array}{l}-0.017 \\
(0.039)\end{array}$ & & & $\begin{array}{l}-0.017 \\
(0.039)\end{array}$ & \\
\hline Lag real govt. I growth & & & $\begin{array}{c}0.051 \\
(0.033)\end{array}$ & & & $\begin{array}{c}0.052 \\
(0.033)\end{array}$ & & & $\begin{array}{c}0.069^{* *} \\
(0.032)\end{array}$ \\
\hline Constant & $\begin{array}{c}3.486 \\
(10.514)\end{array}$ & $\begin{array}{c}13.174 \\
(10.610)\end{array}$ & $\begin{array}{c}77.133^{* * * *} \\
(16.900)\end{array}$ & $\begin{array}{c}-5.646 \\
(10.014)\end{array}$ & $\begin{array}{c}1.848 \\
(10.189)\end{array}$ & $\begin{array}{c}54.741^{* * * *} \\
(18.698)\end{array}$ & $\begin{array}{c}-4.388 \\
(11.451)\end{array}$ & $\begin{array}{c}2.428 \\
(14.604)\end{array}$ & $\begin{array}{c}15.840 \\
(38.553)\end{array}$ \\
\hline Observations & 1,874 & 2,000 & 1,930 & 1,828 & 1,938 & 1,877 & 1,753 & 1,871 & 1,699 \\
\hline R-squared & 0.080 & 0.019 & 0.024 & 0.071 & 0.020 & 0.018 & 0.103 & 0.032 & 0.027 \\
\hline Countries & 115 & 124 & 101 & 113 & 121 & 99 & 116 & 125 & 101 \\
\hline \multicolumn{10}{|l|}{ Dependent variable at $h=1$} \\
\hline US EPU & $\begin{array}{c}-0.027^{* * * *} \\
(0.004)\end{array}$ & $\begin{array}{c}-0.025^{* *} \\
(0.010)\end{array}$ & $\begin{array}{c}-0.118^{* * * *} \\
(0.030)\end{array}$ & & & & & & \\
\hline Lag US EPU & $\begin{array}{c}0.017^{* * * *} \\
(0.004)\end{array}$ & $\begin{array}{c}-0.001 \\
(0.008)\end{array}$ & $\begin{array}{c}0.096^{* * * *} \\
(0.029)\end{array}$ & & & & & & \\
\hline Europe EPU & & & & $\begin{array}{c}-0.021^{* * *} \\
(0.004)\end{array}$ & $\begin{array}{c}-0.029^{* * *} \\
(0.011)\end{array}$ & $\begin{array}{c}-0.080^{* *} \\
(0.031)\end{array}$ & & & \\
\hline Lag Europe EPU & & & & $\begin{array}{c}0.014^{* * *} \\
(0.003)\end{array}$ & $\begin{array}{c}0.011 \\
(0.009)\end{array}$ & $\begin{array}{c}0.073^{* *} \\
(0.029)\end{array}$ & & & \\
\hline China EPU & & & & & & & $\begin{array}{c}-0.015^{* * *} \\
(0.002)\end{array}$ & $\begin{array}{c}-0.026^{* * *} \\
(0.005)\end{array}$ & $\begin{array}{c}-0.045^{* * * *} \\
(0.012)\end{array}$ \\
\hline Lag China EPU & & & & & & & $\begin{array}{c}0.004^{* *} \\
(0.002) \\
\end{array}$ & $\begin{array}{c}0.004 \\
(0.006) \\
\end{array}$ & $\begin{array}{c}0.016 \\
(0.011)\end{array}$ \\
\hline \multicolumn{10}{|l|}{ Dependent variable at $h=2$} \\
\hline US EPU & $\begin{array}{c}0.002 \\
(0.004)\end{array}$ & $\begin{array}{c}-0.012 \\
(0.010)\end{array}$ & $\begin{array}{c}0.004 \\
(0.028)\end{array}$ & & & & & & \\
\hline Lag US EPU & $\begin{array}{c}0.005 \\
(0.004)\end{array}$ & $\begin{array}{c}0.003 \\
(0.009)\end{array}$ & $\begin{array}{l}0.046^{*} \\
(0.026)\end{array}$ & & & & & & \\
\hline Europe EPU & & & & $\begin{array}{c}0.006 \\
(0.004)\end{array}$ & $\begin{array}{l}-0.007 \\
(0.008)\end{array}$ & $\begin{array}{c}0.020 \\
(0.025)\end{array}$ & & & \\
\hline Lag Europe EPU & & & & $\begin{array}{l}-0.005 \\
(0.004)\end{array}$ & $\begin{array}{l}-0.002 \\
(0.010)\end{array}$ & $\begin{array}{c}0.002 \\
(0.025)\end{array}$ & & & \\
\hline China EPU & & & & & & & $\begin{array}{c}0.006^{* * *} \\
(0.002)\end{array}$ & $\begin{array}{c}0.006 \\
(0.006)\end{array}$ & $\begin{array}{c}0.022 \\
(0.014)\end{array}$ \\
\hline Lag China EPU & & & & & & & $\begin{array}{l}-0.001 \\
(0.003)\end{array}$ & $\begin{array}{l}-0.005 \\
(0.004)\end{array}$ & $\begin{array}{c}0.001 \\
(0.017)\end{array}$ \\
\hline \multicolumn{10}{|l|}{ Dependent variable at $h=3$} \\
\hline US EPU & $\begin{array}{c}0.011^{* * *} \\
(0.004)\end{array}$ & $\begin{array}{c}0.004 \\
(0.007)\end{array}$ & $\begin{array}{c}0.080^{* * *} \\
(0.021)\end{array}$ & & & & & & \\
\hline Lag US EPU & $\begin{array}{l}-0.000 \\
(0.004)\end{array}$ & $\begin{array}{l}-0.005 \\
(0.011)\end{array}$ & $\begin{array}{c}0.003 \\
(0.024)\end{array}$ & & & & & & \\
\hline Europe EPU & & & & $\begin{array}{c}0.009^{* *} \\
(0.004)\end{array}$ & $\begin{array}{l}-0.004 \\
(0.007)\end{array}$ & $\begin{array}{c}0.063^{* *} \\
(0.025)\end{array}$ & & & \\
\hline Lag Europe EPU & & & & $\begin{array}{c}-0.009 * * \\
(0.004)\end{array}$ & $\begin{array}{l}-0.001 \\
(0.009)\end{array}$ & $\begin{array}{l}-0.031 \\
(0.024)\end{array}$ & & & \\
\hline China EPU & & & & & & & $\begin{array}{c}0.004 \\
(0.002)\end{array}$ & $\begin{array}{c}0.001 \\
(0.004)\end{array}$ & $\begin{array}{c}0.025 \\
(0.017)\end{array}$ \\
\hline Lag China EPU & & & & & & & $\begin{array}{l}-0.000 \\
(0.002)\end{array}$ & $\begin{array}{l}-0.003 \\
(0.005)\end{array}$ & $\begin{array}{c}0.013 \\
(0.016)\end{array}$ \\
\hline
\end{tabular}

Source: Authors' calculations.

Notes: Regressions for shocks to the US (Europe) [China] EPU exclude the panel of the US (France, Germany, Italy, Spain, UK) [China]. The results of the regressions for horizons $h=1, \ldots, 3$ include all controls but report only the coefficients on EPU. All regressions include country fixed effects. Cluster-robust standard errors in parentheses. ${ }^{* * *} \mathrm{p}<0.01,{ }^{* *} \mathrm{p}<0.05,{ }^{*} \mathrm{p}<0.1$. 
Figure 11: IRFs from Heterogeneous PSVAR with Controls for General Uncertainty, Activity, and Confidence

(Percent)

I: EPU; R: real Y growth
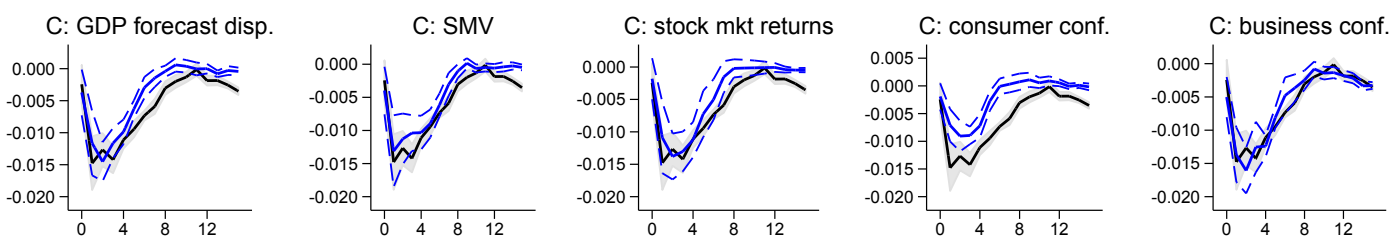

I: EPU; R: real PC growth
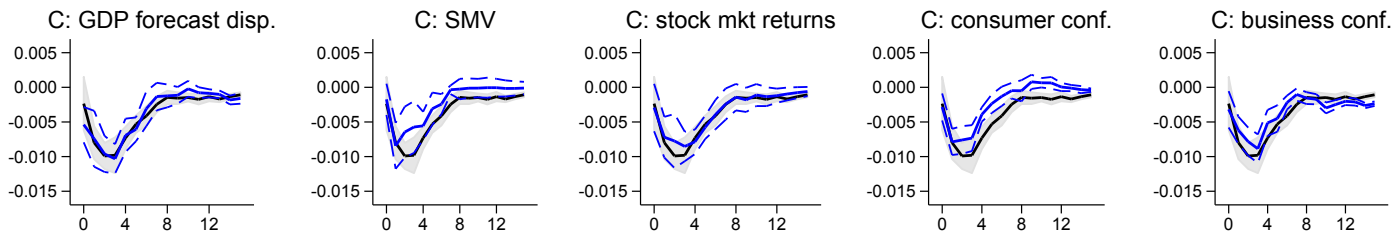

\section{I: EPU; R: real PI growth}
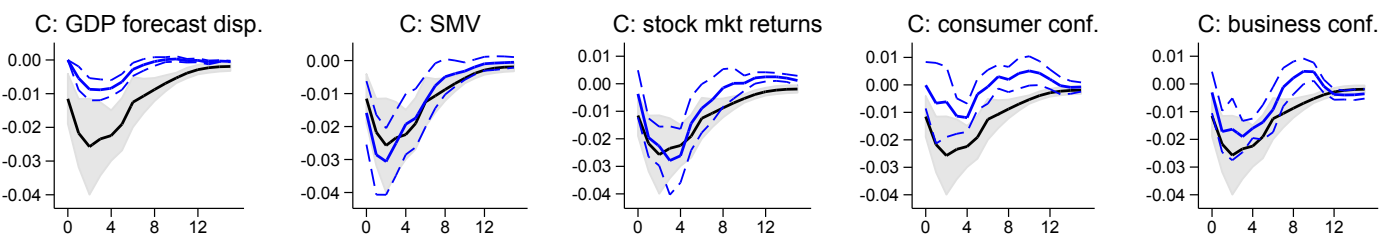

Source: Authors' calculations.

Notes: The blue (black) solid lines represent the median effect generated controlling for a third variable (with the baseline specification), and the dashed blue lines (shaded areas) represent the 95 percent confidence interval calculated from a resampling simulation with 100 repetitions. C stands for control, which is the third variable in the PSVAR.

\subsection{Local Projections}

We explore the robustness of our results by making several changes to the baseline specification estimated with the local projections method. First, and similar to the robustness checks for the PSVAR, we test whether our results are robust when we account for a series of variables proxying general uncertainty, economic activity, and confidence. Table 2 presents the estimates of the response of economic activity to an increase in the EPU index in the US, Europe, or China in the fourth quarter after the shock. The response to EPU uncertainty shocks abroad remains negative and significant when we control for GDP forecasts dispersion and stock market volatility, both of which are proxies for the general level of uncertainty. The decline in private investment in response to a European EPU shock is the only response that ceases to be significant. The size of spillovers from EPU abroad to domestic economic activity is marginally smaller than the baseline response. With the exception of the response of private investment to European EPU, the results are also robust to including stock market returns. Again, the response to an increase in EPU in 
Figure 12: Inverted Ordering of Endogenous Regressors in Heterogeneous PSVAR
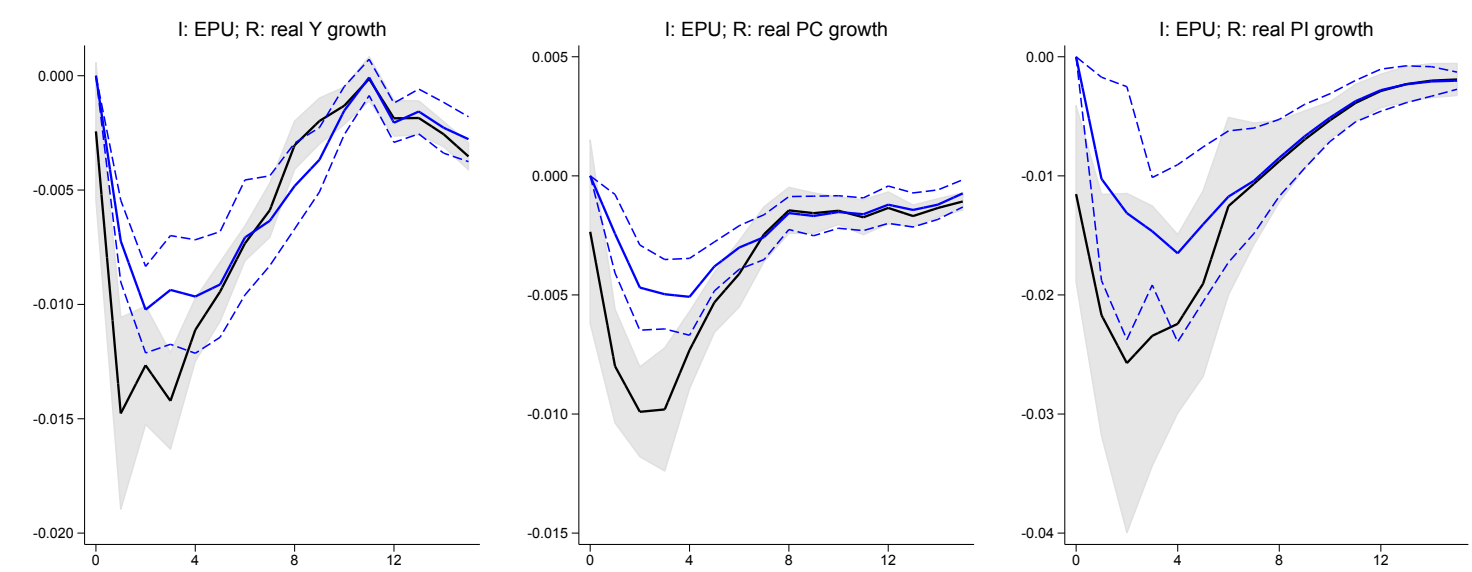

Source: Authors' calculations.

Notes: The blue (black) solid lines represent the median effect generated with inverted (baseline) ordering in the Cholesky decomposition, and the dashed blue lines (shaded areas) represent the 95 percent confidence interval calculated from a resampling simulation with 100 repetitions.

the US, Europe, or China remains negative for growth in real GDP, private consumption, and private investment. Finally, we add measures of consumer and business confidence as controls. Accounting for confidence levels in the economy has little impact on our results.

Second, to ensure that the results do not depend on the extreme events that characterized the GFC, the EPU definition, or the lag structure of the specification, we perform a series of tests. In particular, we repeat the estimations adding a dummy for the GFC period. Also, we define the EPU variable as a dummy that takes the value one when the cyclical component of EPU extracted from a Hodrick-Prescott filter exceeds its mean by more than 1.65 standard deviations or as the percent deviation of EPU from its trend, using alternative EPU definitions. And finally, we modify the lag structure of the specification. The results confirm that our findings are robust to these changes. ${ }^{21}$

Third, we estimate the baseline specification with annual data. While a higher frequency is desirable, the annual data allows a larger sample of 185 countries. The annual local projections in Figure 14 provide a similar picture as the baseline quarterly results. The spillovers of EPU originating abroad to the domestic economy are comparable in magnitude and also lasts for two to three years after the shock.

Finally, we perform another set of estimations to ensure against potential endogeneity arising from reverse causality in the local projections that control for key determinants of growth in GDP, private consumption, and private investment. In Table 1, we simply lag the potentially endogenous regressors. We now employ the two-step system generalized method of moments estimator (SGMM), which aims to take care of the endogeneity concerns by estimating a system of two simultaneous equations, one in levels with lagged first differences as instruments and the other in first differences with lagged levels as instruments. ${ }^{22}$ Compared to the OLS estimations, the S-GMM allows using the regressors contemporaneously rather than their lagged values. Table 3 shows that

\footnotetext{
${ }^{21}$ The results using the dummy for the GFC, alternative measures of EPU, and different lag structures are available upon request.

${ }^{22}$ See Arellano and Bond (1991) and Blundell and Bond (1998) for more details about the S-GMM estimator.
} 
Table 2: Local Projections at $h=4$ with Controls for General Uncertainty, Activity, and Confidence

\begin{tabular}{|c|c|c|c|c|c|c|c|c|c|}
\hline & $\begin{array}{c}(1) \\
\text { Dep: Y }\end{array}$ & $\begin{array}{c}(2) \\
\text { Dep: } \mathrm{PC} \\
\end{array}$ & $\begin{array}{c}(3) \\
\text { Dep PI } \\
\end{array}$ & $\begin{array}{c}(4) \\
\text { Dep: Y }\end{array}$ & $\begin{array}{c}\text { (5) } \\
\text { Dep: PC } \\
\end{array}$ & $\begin{array}{c}(6) \\
\text { Dep PI } \\
\end{array}$ & $\begin{array}{c}(7) \\
\text { Dep: Y }\end{array}$ & $\begin{array}{c}\text { (8) } \\
\text { Dep: PC }\end{array}$ & $\begin{array}{c}(9) \\
\text { Dep PI } \\
\end{array}$ \\
\hline \multicolumn{10}{|l|}{ GDP forecast dispersion } \\
\hline US EPU & $\begin{array}{l}-0.012 * * * \\
(0.02)\end{array}$ & $-0.009^{* * *}$ & $-0.039 * * *$ & & & & & & \\
\hline Lag US EPU & $0.007^{* * *}$ & -0.003 & 0.011 & & & & & & \\
\hline Europe EPU & $(0.003)$ & $(0.002)$ & (0.011) & $-0.007^{* *}$ & $-0.006 * * *$ & -0.017 & & & \\
\hline Lag Europe EPU & & & & $\begin{array}{c}(0.003) \\
0.005^{* * *} \\
(0.02)\end{array}$ & $\begin{array}{c}(0.002) \\
-0.002 \\
(0.002)\end{array}$ & $\begin{array}{c}(0.010) \\
0.025 * * * \\
(0.007)\end{array}$ & & & \\
\hline China EPU & & & & & & & $\begin{array}{c}-0.010^{* * * *} \\
(0.003)\end{array}$ & $\begin{array}{c}-0.009^{* * * *} \\
(0.003)\end{array}$ & $\begin{array}{c}-0.038 * * * \\
(0.006)\end{array}$ \\
\hline Lag China EPU & & & & & & & $\begin{array}{l}0.004 * * \\
(0.002)\end{array}$ & $\begin{array}{l}-0.003 \\
(0.002)\end{array}$ & $\begin{array}{l}0.009^{*} \\
(0.005)\end{array}$ \\
\hline Lag GDP forecast dispersion & $\begin{array}{l}0.474 * * \\
(0.177)\end{array}$ & $\begin{array}{c}0.368 \\
(0.496)\end{array}$ & $\begin{array}{l}1.324^{*} \\
(0.589)\end{array}$ & $\begin{array}{c}0.564^{* * *} \\
(0.170)\end{array}$ & $\begin{array}{c}0.713 \\
(0.404)\end{array}$ & $\begin{array}{c}1.270 \\
(0.672)\end{array}$ & $\begin{array}{l}0.472^{* *} \\
(0.185)\end{array}$ & $\begin{array}{r}0.413 \\
(0.529)\end{array}$ & $\begin{array}{l}1.552^{*} \\
(0.755)\end{array}$ \\
\hline Constant & $\begin{array}{c}2.598^{* * *} \\
(0.645)\end{array}$ & $\begin{array}{l}(0.490) \\
3.033^{* *} \\
(1.195)\end{array}$ & $\begin{array}{c}2.680 \\
(2.288) \\
(288)\end{array}$ & $\begin{array}{c}2.466^{* * *} \\
(0.444)\end{array}$ & 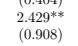 & $\begin{array}{l}-1.027) \\
-1.179 \\
(2.421)\end{array}$ & $\begin{array}{c}\left(0.500^{* * *}\right. \\
(0.536)\end{array}$ & 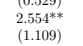 & $\begin{array}{c}(0.59) \\
2.599 \\
(1.812)\end{array}$ \\
\hline Observations & 1,624 & 1,063 & 691 & 1,280 & 719 & 600 & 1,510 & 949 & 697 \\
\hline R-squared & 0.039 & 0.047 & 0.050 & 0.040 & 0.075 & 0.025 & 0.047 & 0.095 & 0.088 \\
\hline Countries & 22 & 14 & 9 & 18 & 10 & 8 & 22 & 14 & 10 \\
\hline \multicolumn{10}{|l|}{ Stock market volatility } \\
\hline US EPU & $-0.018 * * *$ & $-0.017^{* * *}$ & $-0.044^{* * *}$ & & & & & & \\
\hline Lag US EPU & $0.005^{* *}$ & -0.005 & 0.019 & & & & & & \\
\hline Europe EPU & & & & $-0.013^{* * *}$ & $-0.012 * * *$ & $-0.019^{* *}$ & & & \\
\hline Lag Europe EPU & & & & $0.004^{* * *}$ & $\begin{array}{l}-0.002 \\
(0.003)\end{array}$ & $\begin{array}{l}0.033^{* * * * *} \\
(0.006)\end{array}$ & & & \\
\hline China EPU & & & & & & & $-0.016 * * *$ & $\begin{array}{l}-0.015^{* * *} \\
(0.002)\end{array}$ & $-0.038 * * *$ \\
\hline Lag China EPU & & & & & & & $\begin{array}{l}0.005 * * * \\
(0.002)\end{array}$ & $\begin{array}{l}-0.000 \\
0.002)\end{array}$ & $\begin{array}{l}0.009 \\
(0.005)\end{array}$ \\
\hline Lag stock market volatility & $-0.391 * *$ & 0.064 & $\begin{array}{l}-2.661 * * \\
\end{array}$ & $-0.526 * * *$ & -0.242 & $\begin{array}{l}-3.538 * * * \\
(830 *\end{array}$ & $-0.511 * * *$ & -0.252 & $-2.730^{* * * *}$ \\
\hline Constant & $\begin{array}{c}2.911 * * * \\
(0.918)\end{array}$ & $\begin{array}{c}5.612^{* * *} \\
(1.605)\end{array}$ & $\begin{array}{l}-6.840 \\
(6.462)\end{array}$ & $\begin{array}{l}2.015 * * \\
(0.782)\end{array}$ & $\begin{array}{c}3.837^{* * *} \\
(1.355)\end{array}$ & $\begin{array}{c}-15.059^{* * *} \\
(4.346)\end{array}$ & $\begin{array}{l}1.864^{* *} \\
(0.817)\end{array}$ & $\begin{array}{l}3.284^{* *} \\
(1.284)\end{array}$ & $\begin{array}{l}-6.044 \\
(3.702)\end{array}$ \\
\hline Observations & 4,343 & 2,729 & 1,254 & 3.826 & 2,281 & 1,115 & 3,420 & 2,189 & 1,009 \\
\hline R-squared & 0.032 & 0.043 & 0.046 & 0.019 & 0.030 & 0.034 & 0.053 & 0.065 & 0.115 \\
\hline Countries & 49 & 31 & 13 & 45 & 27 & 12 & 49 & 31 & 14 \\
\hline \multicolumn{10}{|l|}{ Stock market returns } \\
\hline US EPU & $-0.015^{* * * *}$ & $-0.013^{* * * *}$ & $-0.038^{* * * *}$ & & & & & & \\
\hline Lag US EPU & $\begin{array}{l}(0.002) \\
0.005 * *\end{array}$ & $\begin{array}{l}(0.002) \\
-0.003\end{array}$ & $\begin{array}{c}(0.007) \\
0.014\end{array}$ & & & & & & \\
\hline & $(0.002)$ & $(0.002)$ & $(0.010)$ & & & & & & \\
\hline Europe EPU & & & & $-0.010^{* * * *}$ & $-0.009 * * *$ & -0.010 & & & \\
\hline Lag Europe EPU & & & & $\begin{array}{l}0.004^{* * *} \\
(0.01)\end{array}$ & $\begin{array}{l}-0.003 \\
(0.002)\end{array}$ & $\begin{array}{c}0.025 * * * \\
(0.005)\end{array}$ & & & \\
\hline China EPU & & & & & & & $\begin{array}{c}-0.013 * * * \\
(0.002)\end{array}$ & $\begin{array}{l}-0.012 * * * \\
(0.002)\end{array}$ & $\begin{array}{l}\left.-0.034^{* * *}\right) \\
(0.006)\end{array}$ \\
\hline Lag China EPU & & & & & & & $\begin{array}{c}0.004^{* * *} \\
(0.001)\end{array}$ & $\begin{array}{l}-0.001 \\
(0.002)\end{array}$ & $\begin{array}{c}0.004 \\
(0.005)\end{array}$ \\
\hline Lag stock market returns & $\begin{array}{c}3.3611^{* * *} \\
(0.570)\end{array}$ & $\begin{array}{c}3.447 * * * \\
(1.120)\end{array}$ & $\begin{array}{c}10.734^{* *} \\
(4.144)\end{array}$ & $\begin{array}{c}3.762^{* * *} \\
(0.632)\end{array}$ & $\begin{array}{l}4.165 * * * \\
(1.306)\end{array}$ & $\begin{array}{c}14.799 * * * \\
(4.299)\end{array}$ & $\begin{array}{c}4.048^{* * * *} \\
(0.561)\end{array}$ & $\begin{array}{l}4.050 * * * * \\
(1.237)\end{array}$ & $\begin{array}{c}11.072^{* * *} \\
(2.954)\end{array}$ \\
\hline Constant & $\begin{array}{l}4.262^{* * *} \\
(0.288)\end{array}$ & $\begin{array}{c}4.722 * * * \\
(0.367)\end{array}$ & $\begin{array}{c}5.036 * * * \\
(1.634)\end{array}$ & $\begin{array}{l}4.087^{* * *} \\
(0.197)\end{array}$ & $\begin{array}{l}4.618^{* * * *} \\
(0.371)\end{array}$ & $\begin{array}{l}0.828 \\
(0.995)\end{array}$ & $\begin{array}{c}3.927^{* * *} \\
(0.233)\end{array}$ & $\begin{array}{l}4.120^{* * * *} \\
(0.264)\end{array}$ & $\begin{array}{l}6.112^{* * *} \\
(0.936)\end{array}$ \\
\hline Observations & 4,343 & 2,729 & 1,254 & 3,826 & 2,281 & 1,115 & 3,420 & 2,189 & 1,009 \\
\hline R-squared & 0.050 & 0.060 & 0.051 & 0.042 & 0.054 & 0.044 & 0.076 & 0.088 & 0.120 \\
\hline Countries & 49 & 31 & 13 & 45 & 27 & 12 & 49 & 31 & 14 \\
\hline \multicolumn{10}{|l|}{ Consumer confidence } \\
\hline US EPU & $\begin{array}{c}-0.021 * * * * \\
(0.002)\end{array}$ & $\begin{array}{c}-0.016^{* * *} \\
(0.002)\end{array}$ & $\begin{array}{c}-0.043^{* * * *} \\
(0.009)\end{array}$ & & & & & & \\
\hline Lag US EPU & $\begin{array}{l}0.001 \\
(0.002)\end{array}$ & $\begin{array}{c}-0.005 * * \\
(0.002)\end{array}$ & $\begin{array}{l}0.013 \\
(0.009)\end{array}$ & & & & & & \\
\hline Europe EPU & & & & $\begin{array}{c}-0.016^{* * * *} \\
(0.002)\end{array}$ & $\begin{array}{c}-0.013 * * * \\
(0.002)\end{array}$ & $\begin{array}{l}-0.018^{*} \\
(0.008)\end{array}$ & & & \\
\hline Lag Europe EPU & & & & 0.003 & -0.004 & $0.027^{* * * *}$ & & & \\
\hline China EPU & & & & & & & $-0.017^{* * *}$ & $-0.012^{* * *}$ & $-0.033 * * *$ \\
\hline Lag China EPU & & & & & & & $(0.001)$ & $(0.002)$ & $(0.004)$ \\
\hline Lag China EPU & & & & & & & $\begin{array}{l}0.000 \\
(0.001)\end{array}$ & $\begin{array}{l}-0.002 \\
(0.001)\end{array}$ & -0.001 \\
\hline Lag consumer confidence & 0.090 & 0.150 & 0.472 & 0.108 & 0.124 & 0.790 & 0.074 & 0.171 & -0.402 \\
\hline & $(0.127)$ & $(0.137)$ & $(0.539)$ & $(0.138)$ & $(0.142)$ & $(0.533)$ & $(0.113)$ & $(0.125)$ & $(0.290)$ \\
\hline Constant & $\begin{array}{c}-4.149 \\
-1.023\end{array}$ & $\begin{array}{l}-10.188 \\
\end{array}$ & -41.507 & $\begin{array}{r}-6.383 \\
-1401\end{array}$ & $\begin{array}{r}-7.669 \\
-14388\end{array}$ & $\begin{array}{r}-77.478 \\
65.781\end{array}$ & $\begin{array}{r}-3.044 \\
-01354\end{array}$ & -13.216 & 46.721 \\
\hline & & & & & & & & & \\
\hline Observations & 3,240 & 2,646 & 1,161 & 2,723 & 2,166 & 1,029 & 2,670 & 2,176 & 1,022 \\
\hline $\begin{array}{l}\text { R-squared } \\
\text { Coumtries }\end{array}$ & $\begin{array}{c}0.065 \\
36\end{array}$ & $\begin{array}{c}0.075 \\
29\end{array}$ & $\begin{array}{c}0.043 \\
12\end{array}$ & $\begin{array}{c}0.043 \\
32\end{array}$ & $\begin{array}{c}0.069 \\
25\end{array}$ & $\begin{array}{l}0.027 \\
11\end{array}$ & $\begin{array}{c}0.113 \\
36\end{array}$ & $\begin{array}{l}0.108 \\
29\end{array}$ & $\begin{array}{l}0.085 \\
13\end{array}$ \\
\hline \multicolumn{10}{|l|}{ Business confidence } \\
\hline US EPU & $-0.020^{* * * *}$ & $-0.015^{* * *}$ & $-0.043^{* * *}$ & & & & & & \\
\hline Lag US EPU & $(0.002)$ & $(0.002)$ & & & & & & & \\
\hline & $\begin{array}{l}0.002 \\
(0.002)\end{array}$ & $\begin{array}{l}-0.001 \\
(0.002)\end{array}$ & $\begin{array}{l}0.011 \\
(0.012)\end{array}$ & & & & & & \\
\hline Europe EPU & & & & $-0.014^{* * *}$ & $-0.013 * * *$ & $-0.021 * * *$ & & & \\
\hline Lag Europe EPU & & & & ${ }_{0.002 *}^{(0.002)}$ & ${ }_{-0.001}^{(0.002)}$ & $\begin{array}{l}(0.007) \\
0.020^{* *}\end{array}$ & & & \\
\hline & & & & $(0.001)$ & $(0.002)$ & $(0.008)$ & & & \\
\hline China EPU & & & & & & & $0.016^{* * * *}$ & $-0.012^{* * *}$ & $-0.032 * * *$ \\
\hline Lag China EPU & & & & & & & & $(0.002)$ & $(0.004)$ \\
\hline & & & & & & & 0.001 & -0.000 & 0.001 \\
\hline Lag business confidence & 0.128 & $0.284^{* *}$ & 0.144 & 0.150 & $0.281^{* *}$ & 0.463 & 0.009 & $0.225^{*}$ & 0.060 \\
\hline & $(0.095)$ & $(0.111)$ & $(0.491)$ & $(0.094)$ & $(0.112)$ & $(0.482)$ & $(0.088)$ & $(0.117)$ & $(0.388)$ \\
\hline Constant & $\begin{array}{l}-8.224 \\
(9.626)\end{array}$ & $\begin{array}{c}-23.954^{* *} \\
(11.059)\end{array}$ & $\begin{array}{r}-8.146 \\
(50.137)\end{array}$ & $\begin{array}{l}-10.675 \\
(9.361)\end{array}$ & $\begin{array}{c}-23.501^{* *} \\
(11.098)\end{array}$ & $\begin{array}{r}-43.303 \\
(49.126)\end{array}$ & $\begin{array}{l}3.391 \\
(8.788)\end{array}$ & $\begin{array}{l}-18.829 \\
(11.699)\end{array}$ & $\begin{array}{c}0.178 \\
(39.435)\end{array}$ \\
\hline Observations & 3.613 & 2.759 & 1.227 & 3.088 & 2.27 & 1.103 & 3.043 & 2.317 & 1.105 \\
\hline R-squared & 0.051 & 0.060 & 0.035 & 0.038 & 0.063 & 0.011 & 0.091 & 0.077 & 0.075 \\
\hline Countries & 39 & 29 & 13 & 35 & 25 & 12 & 39 & 29 & 14 \\
\hline
\end{tabular}


Figure 13: Estimation of Heterogeneous PSVAR with Annual Data

I: EPU; R: real Y growth

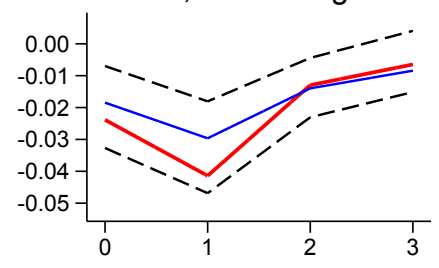

I: EPU; R: real Y growth

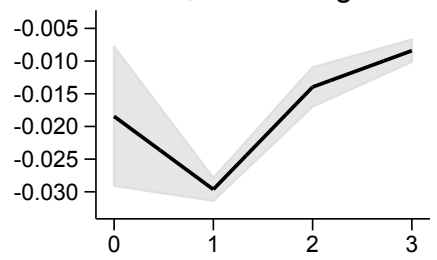

I: EPU; R: real Y growth

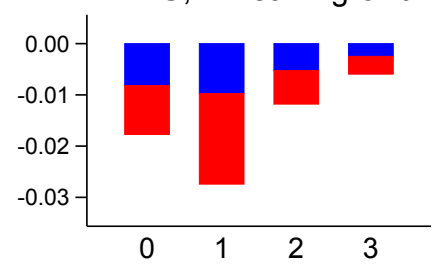

I: EPU; R: real PC growth

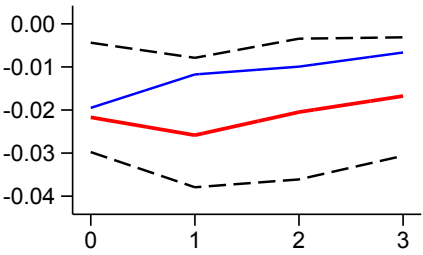

I: EPU; R: real PC growth

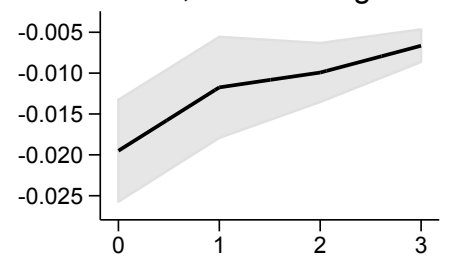

I: EPU; R: real PC growth

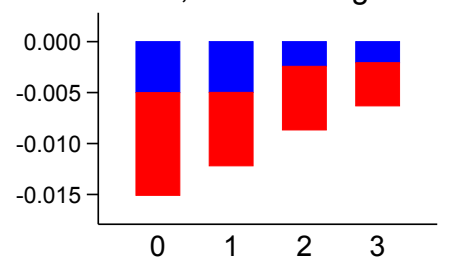

I: EPU; R: real PI growth

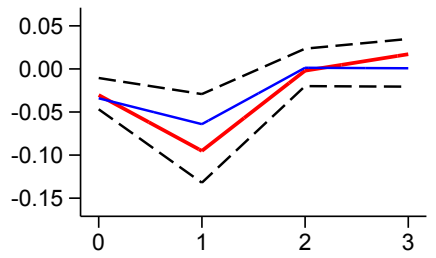

I: EPU; R: real PI growth

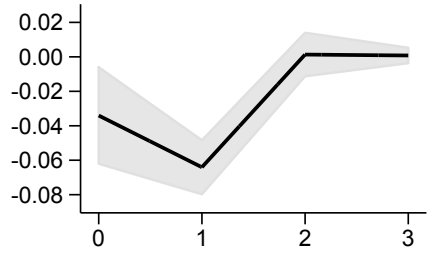

I: EPU; R: real PI growth

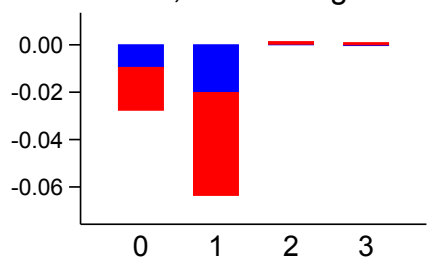

Source: Authors' calculations.

Notes: The blue (red) lines represent the median (average) effect, the dashed black lines represent the $25^{\text {th }}$ and $75^{\text {th }}$ percentiles.

The black lines represent the median effect, the shaded area represents the 95 percent confidence interval calculated from

a resampling simulation with 100 repetitions. Blue (red) bars represent median responses to idiosyncratic (common) shocks.

the trough in year one remains of the same magnitude and statistically significant. While the significance levels of the responses at other horizons change for some of the local projections, the results remain qualitatively unchanged.

\section{Conclusions}

High levels of EPU in recent years invigorated the interest in its relationship with economic outcomes. The empirical evidence generally confirms the theoretical prediction for which economic agents withhold consumption and investment decisions until uncertainty about a certain policy or a reform resolves, thereby depressing economic activity. These studies, however, often look at the domestic effects of EPU. Our paper belongs to a different niche of this literature, which focuses on spillovers of EPU shocks.

Employing two complementary econometric techniques, we first disentangle the overall effect of 
Table 3: Local Projections with Controls for Main Determinants of Y, PC, and PI with Annual Data (S-GMM)

\begin{tabular}{|c|c|c|c|c|c|c|c|c|c|}
\hline & $\begin{array}{c}(1) \\
\text { Dep: Y }\end{array}$ & $\begin{array}{c}(2) \\
\text { Dep: PC } \\
\end{array}$ & $\begin{array}{c}(3) \\
\text { Dep PI } \\
\end{array}$ & $\begin{array}{c}(4) \\
\text { Dep: Y }\end{array}$ & $\begin{array}{c}\text { (5) } \\
\text { Dep: PC }\end{array}$ & $\begin{array}{c}(6) \\
\text { Dep PI } \\
\end{array}$ & $\begin{array}{c}(7) \\
\text { Dep: Y }\end{array}$ & $\begin{array}{c}(8) \\
\text { Dep: PC } \\
\end{array}$ & $\begin{array}{c}(9) \\
\text { Dep PI } \\
\end{array}$ \\
\hline \multicolumn{10}{|l|}{ Dependent variable at $h=0$} \\
\hline US EPU & $\begin{array}{l}-0.006 \\
(0.005)\end{array}$ & $\begin{array}{c}-0.019^{* *} \\
(0.008)\end{array}$ & $\begin{array}{l}-0.008 \\
(0.027)\end{array}$ & & & & & & \\
\hline Lag US EPU & $\begin{array}{c}-0.020^{* *} \\
(0.009)\end{array}$ & $\begin{array}{l}-0.017^{*} \\
(0.009)\end{array}$ & $\begin{array}{c}-0.080^{* *} \\
(0.034)\end{array}$ & & & & & & \\
\hline Europe EPU & & & & $\begin{array}{c}0.002 \\
(0.006)\end{array}$ & $\begin{array}{l}-0.004 \\
(0.008)\end{array}$ & $\begin{array}{c}0.010 \\
(0.032)\end{array}$ & & & \\
\hline Lag Europe EPU & & & & $\begin{array}{c}-0.016^{* * *} \\
(0.005)\end{array}$ & $\begin{array}{c}-0.020^{* *} \\
(0.008)\end{array}$ & $\begin{array}{c}-0.060^{* *} \\
(0.030)\end{array}$ & & & \\
\hline China EPU & & & & & & & $\begin{array}{c}-0.013^{* * *} \\
(0.002)\end{array}$ & $\begin{array}{l}-0.009 \\
(0.007)\end{array}$ & $\begin{array}{c}-0.039 \text { *** } \\
(0.015)\end{array}$ \\
\hline Lag China EPU & & & & & & & $\begin{array}{c}-0.010^{* * *} \\
(0.003)\end{array}$ & $\begin{array}{c}-0.024^{* *} \\
(0.012)\end{array}$ & $\begin{array}{c}-0.040^{* * * *} \\
(0.013)\end{array}$ \\
\hline Lag dependent variable & $\begin{array}{l}-0.003 \\
(0.207)\end{array}$ & $\begin{array}{l}-0.006 \\
(0.268)\end{array}$ & 0.019 & $\begin{array}{l}-0.020 \\
(0.186)\end{array}$ & $\begin{array}{l}-0.115 \\
(0.161)\end{array}$ & $\begin{array}{c}0.004 \\
(0.133)\end{array}$ & $\begin{array}{c}0.321^{* * *} \\
(0.079)\end{array}$ & $\begin{array}{l}0.299 \\
(0.673)\end{array}$ & $\begin{array}{l}-0.116 \\
(0.099)\end{array}$ \\
\hline Ln real per capita GDP & $\begin{array}{l}-0.049 \\
(0.070)\end{array}$ & $\begin{array}{l}-0.085 \\
(0.121)\end{array}$ & $\begin{array}{c}0.306 \\
(0.346)\end{array}$ & $\begin{array}{l}-0.044 \\
(0.064)\end{array}$ & $\begin{array}{l}-0.020 \\
(0.107)\end{array}$ & $\begin{array}{c}0.320 \\
(0.421)\end{array}$ & $\begin{array}{l}-0.035 \\
(0.042)\end{array}$ & $\begin{array}{c}0.010 \\
(0.132)\end{array}$ & $\begin{array}{l}-0.216 \\
(0.386)\end{array}$ \\
\hline ToT growth & $\begin{array}{c}0.028 \\
(0.028)\end{array}$ & $\begin{array}{l}-0.016 \\
(0.041)\end{array}$ & $\begin{array}{l}-0.011 \\
(0.056)\end{array}$ & $\begin{array}{c}0.034 \\
(0.023)\end{array}$ & $\begin{array}{l}-0.023 \\
(0.034)\end{array}$ & $\begin{array}{l}-0.025 \\
(0.084)\end{array}$ & $\begin{array}{c}0.005 \\
(0.010)\end{array}$ & $\begin{array}{l}-0.064 \\
(0.053)\end{array}$ & $\begin{array}{c}0.072 \\
(0.057)\end{array}$ \\
\hline Real oil price & $\begin{array}{l}0.027^{* *} \\
(0.014)\end{array}$ & $\begin{array}{c}0.025 \\
(0.020)\end{array}$ & $\begin{array}{c}0.029 \\
(0.042)\end{array}$ & $\begin{array}{c}0.026^{* *} \\
(0.013)\end{array}$ & $\begin{array}{c}0.037^{* *} \\
(0.015)\end{array}$ & $\begin{array}{c}0.024 \\
(0.052)\end{array}$ & $\begin{array}{l}0.014^{* *} \\
(0.006)\end{array}$ & $\begin{array}{c}0.052 \\
(0.041)\end{array}$ & $\begin{array}{l}0.103^{* *} \\
(0.052)\end{array}$ \\
\hline Old-age dependency ratio & $\begin{array}{c}-0.111 * * \\
(0.046)\end{array}$ & $\begin{array}{c}-0.191 * * \\
(0.089)\end{array}$ & & $\begin{array}{c}-0.117^{* * *} \\
(0.041)\end{array}$ & $\begin{array}{c}-0.170^{* * *} \\
(0.045)\end{array}$ & & $\begin{array}{c}-0.090^{* * *} \\
(0.017)\end{array}$ & $\begin{array}{l}-0.082 \\
(0.092)\end{array}$ & \\
\hline Share of ubran population & $\begin{array}{l}-0.016 \\
(0.012)\end{array}$ & $\begin{array}{c}0.009 \\
(0.011)\end{array}$ & & $\begin{array}{c}-0.016 \\
(0.010)\end{array}$ & $\begin{array}{c}0.012 \\
(0.013)\end{array}$ & & $\begin{array}{l}-0.011^{*} \\
(0.006)\end{array}$ & $\begin{array}{l}0.008 \\
(0.016)\end{array}$ & \\
\hline Inflation & $\begin{array}{c}0.053 \\
(0.098)\end{array}$ & $\begin{array}{l}-0.016 \\
(0.139)\end{array}$ & $\begin{array}{l}-0.021 \\
(0.026)\end{array}$ & $\begin{array}{c}0.048 \\
(0.081)\end{array}$ & $\begin{array}{c}0.058 \\
(0.088)\end{array}$ & $\begin{array}{l}-0.019 \\
(0.029)\end{array}$ & $\begin{array}{l}-0.043 \\
(0.037)\end{array}$ & $\begin{array}{c}0.166 \\
(0.247)\end{array}$ & $\begin{array}{c}0.418 \\
(0.379)\end{array}$ \\
\hline Real appreciation & $\begin{array}{c}0.277 \\
(0.395)\end{array}$ & $\begin{array}{c}0.180 \\
(0.147)\end{array}$ & $\begin{array}{l}-0.040 \\
(0.090)\end{array}$ & $\begin{array}{c}0.327 \\
(0.257)\end{array}$ & $\begin{array}{c}0.151 \\
(0.107)\end{array}$ & $\begin{array}{l}-0.066 \\
(0.092)\end{array}$ & $\begin{array}{c}0.021 \\
(0.029)\end{array}$ & $\begin{array}{l}-0.151 \\
(0.418)\end{array}$ & $\begin{array}{l}-0.070 \\
(0.093)\end{array}$ \\
\hline Real interest rate & $\begin{array}{c}0.284 \\
(0.306)\end{array}$ & $\begin{array}{c}0.005 \\
(0.392)\end{array}$ & $\begin{array}{c}-0.734^{* *} \\
(0.368)\end{array}$ & $\begin{array}{c}0.300 \\
(0.229)\end{array}$ & $\begin{array}{c}0.174 \\
(0.246)\end{array}$ & $\begin{array}{c}-0.940 * * \\
(0.478)\end{array}$ & $\begin{array}{c}-0.223^{* *} \\
(0.099)\end{array}$ & $\begin{array}{c}0.234 \\
(0.456)\end{array}$ & $\begin{array}{l}-0.281 \\
(0.714)\end{array}$ \\
\hline Flow of private sector credit growth & $\begin{array}{c}0.157 \\
(0.113)\end{array}$ & $\begin{array}{c}0.103 \\
(0.089)\end{array}$ & $\begin{array}{c}1.798^{* * *} \\
(0.666)\end{array}$ & $\begin{array}{c}0.199^{* *} \\
(0.090)\end{array}$ & $\begin{array}{l}0.082^{*} \\
(0.047)\end{array}$ & $\begin{array}{c}1.798 * * * \\
(0.666)\end{array}$ & $\begin{array}{c}0.208^{* * *} \\
(0.052)\end{array}$ & $\begin{array}{c}0.055 \\
(0.132)\end{array}$ & $\begin{array}{c}1.822^{* * *} \\
(0.492)\end{array}$ \\
\hline Real govt. purchases growth & $\begin{array}{c}0.023 \\
(0.166)\end{array}$ & & & $\begin{array}{c}0.016 \\
(0.137)\end{array}$ & & & $\begin{array}{c}0.078^{* * * *} \\
(0.021)\end{array}$ & & \\
\hline Real govt. $\mathrm{C}$ growth & & $\begin{array}{l}-0.104 \\
(0.112)\end{array}$ & & & $\begin{array}{l}-0.022 \\
(0.085)\end{array}$ & & & $\begin{array}{l}-0.097 \\
(0.404)\end{array}$ & \\
\hline Real govt. I growth & & & $\begin{array}{l}-0.063 \\
(0.048)\end{array}$ & & & $\begin{array}{l}-0.051 \\
(0.053)\end{array}$ & & & $\begin{array}{l}-0.104^{*} \\
(0.054)\end{array}$ \\
\hline Constant & $\begin{array}{l}6.672^{* *} \\
(2.894)\end{array}$ & $\begin{array}{l}9.084^{* *} \\
(4.447)\end{array}$ & $\begin{array}{c}3.132 \\
(5.246)\end{array}$ & $\begin{array}{l}5.492^{* *} \\
(2.378)\end{array}$ & $\begin{array}{c}6.051^{* * *} \\
(2.106)\end{array}$ & $\begin{array}{l}-0.621 \\
(5.599)\end{array}$ & $\begin{array}{c}5.884^{* * *} \\
(1.005)\end{array}$ & $\begin{array}{c}3.074 \\
(4.945)\end{array}$ & $\begin{array}{l}1.777 \\
(5.941)\end{array}$ \\
\hline Observations & 1,976 & 2,094 & 1,829 & 1,927 & 2,028 & 1,777 & 1,812 & 1,930 & 1,598 \\
\hline Countries & 115 & 124 & 101 & 113 & 121 & 99 & 115 & 124 & 101 \\
\hline $\mathrm{p}$-value $\mathrm{AR}(2)$ & 0.157 & 0.518 & 0.444 & 0.194 & 0.708 & 0.484 & 0.195 & 0.425 & 0.593 \\
\hline p-value Hansen test & 0.844 & 0.232 & 0.242 & 0.843 & 0.129 & 0.194 & 0.338 & 0.134 & 0.829 \\
\hline \multicolumn{10}{|l|}{ Dependent variable at $h=1$} \\
\hline US EPU & $\begin{array}{c}-0.028^{* * *} \\
(0.005)\end{array}$ & $\begin{array}{c}-0.020^{* *} \\
(0.009)\end{array}$ & $\begin{array}{c}-0.145^{* * *} \\
(0.033)\end{array}$ & & & & & & \\
\hline Lag US EPU & $\begin{array}{c}0.026^{* * * *} \\
(0.005)\end{array}$ & $\begin{array}{c}0.002 \\
(0.009)\end{array}$ & $\begin{array}{c}0.161^{* * *} \\
(0.033)\end{array}$ & & & & & & \\
\hline Europe EPU & & & & $\begin{array}{c}-0.025^{* * *} \\
(0.006)\end{array}$ & $\begin{array}{l}-0.022^{*} \\
(0.012)\end{array}$ & $\begin{array}{c}-0.096^{* * *} \\
(0.034)\end{array}$ & & & \\
\hline Lag Europe EPU & & & & $\begin{array}{c}0.028^{* * *} \\
(0.005)\end{array}$ & $\begin{array}{c}0.018 \\
(0.011)\end{array}$ & $\begin{array}{c}0.134^{* * *} \\
(0.036)\end{array}$ & & & \\
\hline China EPU & & & & & & & $\begin{array}{c}-0.010^{* * *} \\
(0.004)\end{array}$ & $\begin{array}{c}-0.020^{* * * *} \\
(0.005)\end{array}$ & $\begin{array}{c}-0.050^{* *} \\
(0.021)\end{array}$ \\
\hline Lag China EPU & & & & & & & $\begin{array}{l}0.009^{*} \\
(0.005) \\
\end{array}$ & $\begin{array}{c}0.008 \\
(0.005) \\
\end{array}$ & $\begin{array}{c}0.012 \\
(0.017) \\
\end{array}$ \\
\hline \multicolumn{10}{|l|}{ Dependent variable at $h=2$} \\
\hline US EPU & $\begin{array}{c}0.017^{* * *} \\
(0.005)\end{array}$ & $\begin{array}{l}-0.005 \\
(0.010)\end{array}$ & $\begin{array}{c}0.044 \\
(0.029)\end{array}$ & & & & & & \\
\hline Lag US EPU & $\begin{array}{l}-0.005 \\
(0.006)\end{array}$ & $\begin{array}{c}0.008 \\
(0.011)\end{array}$ & $\begin{array}{c}0.020 \\
(0.030)\end{array}$ & & & & & & \\
\hline Europe EPU & & & & $\begin{array}{l}0.011^{* *} \\
(0.005)\end{array}$ & $\begin{array}{c}0.001 \\
(0.010)\end{array}$ & $\begin{array}{c}0.027 \\
(0.028)\end{array}$ & & & \\
\hline Lag Europe EPU & & & & $\begin{array}{l}-0.010 \\
(0.007)\end{array}$ & $\begin{array}{l}-0.005 \\
(0.013)\end{array}$ & $\begin{array}{l}-0.010 \\
(0.034)\end{array}$ & & & \\
\hline China EPU & & & & & & & $\begin{array}{l}0.011^{* *} \\
(0.005)\end{array}$ & $\begin{array}{c}0.004 \\
(0.016)\end{array}$ & $\begin{array}{c}0.017 \\
(0.014)\end{array}$ \\
\hline Lag China EPU & & & & & & & $\begin{array}{l}-0.002 \\
(0.004)\end{array}$ & $\begin{array}{r}0.003 \\
(0.006) \\
\end{array}$ & $\begin{array}{c}0.003 \\
(0.014) \\
\end{array}$ \\
\hline \multicolumn{10}{|l|}{ Dependent variable at $h=3$} \\
\hline US EPU & $\begin{array}{c}0.004 \\
(0.008)\end{array}$ & $\begin{array}{c}0.008 \\
(0.010)\end{array}$ & $\begin{array}{c}0.034 \\
(0.051)\end{array}$ & & & & & & \\
\hline Lag US EPU & $\begin{array}{c}0.001 \\
(0.007)\end{array}$ & $\begin{array}{l}-0.001 \\
(0.014)\end{array}$ & $\begin{array}{c}0.003 \\
(0.051)\end{array}$ & & & & & & \\
\hline Europe EPU & & & & $\begin{array}{c}0.008 \\
(0.008)\end{array}$ & $\begin{array}{l}-0.002 \\
(0.010)\end{array}$ & $\begin{array}{c}0.035 \\
(0.045)\end{array}$ & & & \\
\hline Lag Europe EPU & & & & $\begin{array}{l}-0.002 \\
(0.006)\end{array}$ & $\begin{array}{l}-0.001 \\
(0.009)\end{array}$ & $\begin{array}{l}-0.017 \\
(0.043)\end{array}$ & & & \\
\hline China EPU & & & & & & & $\begin{array}{c}0.001 \\
(0.006)\end{array}$ & $\begin{array}{c}0.001 \\
(0.004)\end{array}$ & $\begin{array}{c}0.011 \\
(0.015)\end{array}$ \\
\hline Lag China EPU & & & & & & & $\begin{array}{c}0.001 \\
(0.003)\end{array}$ & $\begin{array}{l}-0.004 \\
(0.005)\end{array}$ & $\begin{array}{l}-0.005 \\
(0.018)\end{array}$ \\
\hline
\end{tabular}

Notes: Regressions for shocks to the US (Europe) [China] EPU exclude the panel of the US (France, Germany, Italy, Spain, UK) [China]. The specifcations use a collapsed instrument matrix and perform the Windmeijer (2005) correction of the covariance matrix. The results of the regressions for $h=1, \ldots, 3$ include all controls but report only the coefficient for EPU. All regressions include country fixed effects. Cluster- 

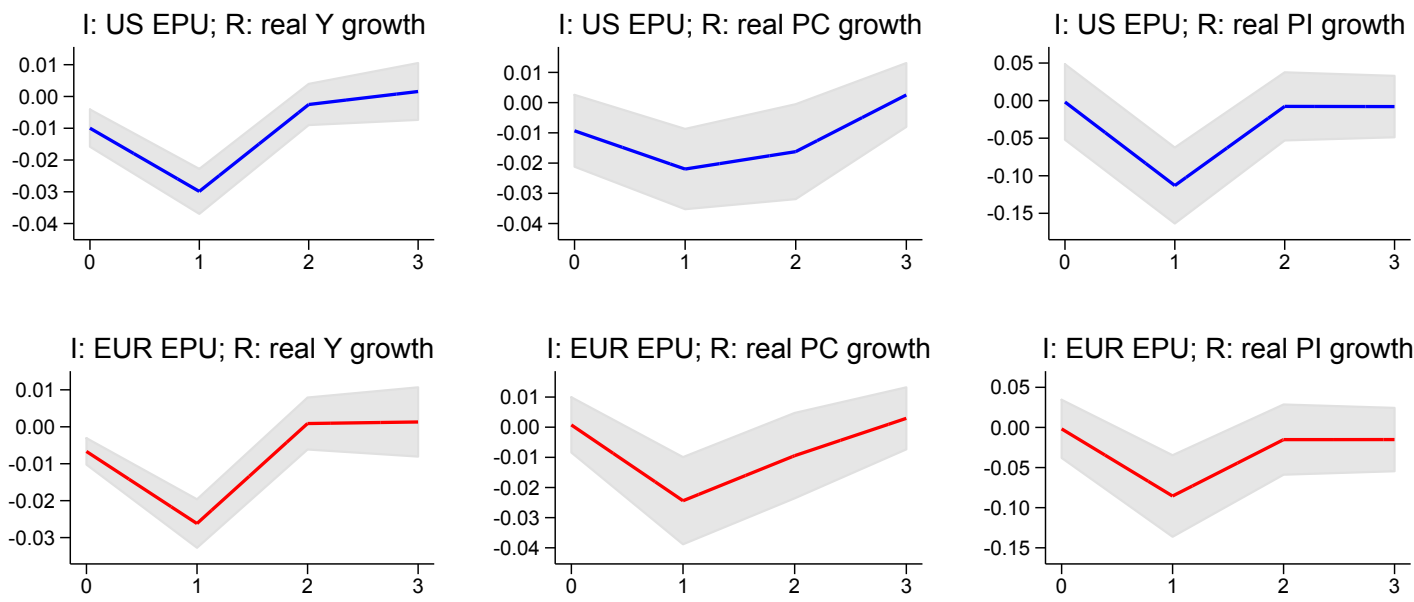

I: CHN EPU; R: real Y growth
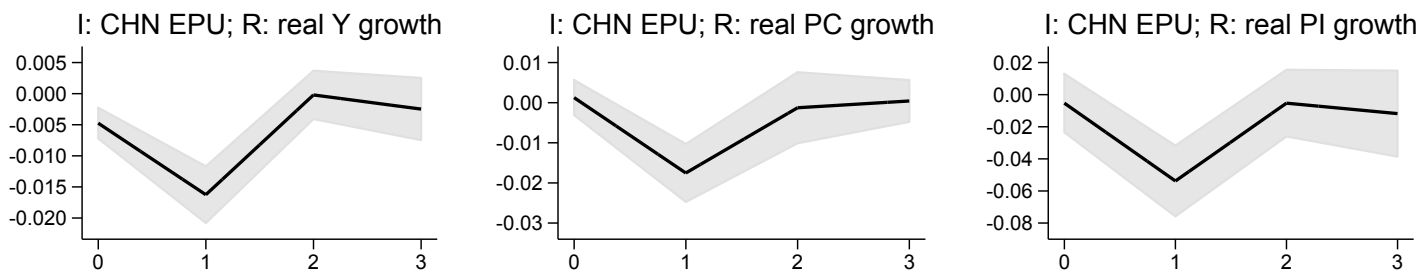

Source: Authors' calculations.

Notes: IRFs for shocks to the United States (Europe) [China] EPU exclude the response of the United States (Germany, Italy, France, Spain, and the United Kingdom) [China]. The shaded areas represent the 95 percent confidence intervals.

EPU into spillovers and the effect of domestic shocks. Subsequently, we focus on the spillovers of EPU shocks in the three largest economies or groups of economies worldwide - the US, Europe, and China - to macroeconomic aggregates in the rest of the world. Moreover, we analyze regional heterogeneity in response to these EPU shocks. In line with the literature, we find that EPU shocks are associated with declines in the real growth of output, private consumption, and private investment. Spillovers are the key driver of the negative impact of uncertainty on domestic macroeconomic aggregates, accounting for about two-thirds of the negative effect. Furthermore, surges in EPU in the US, Europe, and China depress economic activity in other countries up to about two years following the shock. This effect is mostly felt in Europe and the Western Hemisphere.

Our results imply that policy decisions - where possible - should be clearly and timely communicated. In addition, credible commitments to policy implementation may be helpful in minimizing the risk of economic agents adopting a "wait-and-see" approach. At the same time, sound policy frameworks, sufficient policy buffers, and strong fundamentals in recipient economies can help mitigate the effects of uncertainty shocks. More specific policy responses, though, may vary across countries depending on the available policy mix, the strength of the exposure, and their openness. 


\section{References}

Abel, Andrew B (1983). "Optimal Investment Under Uncertainty". In: The American Economic Review 73.1, pp. 228-233.

Alexopoulos, Michelle and Jon S Cohen (2015). "The Power of Print: Uncertainty Shocks, Markets, and the Economy". In: International Review of Economics \& Finance 40, pp. 8-28.

Arellano, Cristina, Yan Bai, and Patrick Kehoe (2010). "Financial Markets and Fluctuations in Uncertainty". In: Federal Reserve Bank of Minneapolis Working Paper.

Arellano, Manuel and Stephen Bond (1991). "Some Tests of Specification for Panel Data: Monte Carlo Evidence and an Application to Employment Equations". In: The review of Economic Studies 58.2, pp. 277-297.

Bachmann, Rüdiger, Steffen Elstner, and Eric R Sims (2013). "Uncertainty and Economic Activity: Evidence from Business Survey Data". In: American Economic Journal: Macroeconomics 5.2 , pp. $217-49$.

Baker, Scott R and Nicholas Bloom (2013). "Does Uncertainty Reduce Growth? Using Disasters as Natural Experiments". In: National Bureau of Economic Research Working Paper No. 19475.

Baker, Scott R, Nicholas Bloom, and Steven J Davis (2016). "Measuring Economic Policy Uncertainty". In: The Quarterly Journal of Economics 131.4, pp. 1593-1636.

Bar-Ilan, Avner and William C. Strange (1996). "Investment Lags". In: The American Economic Review 86.3, pp. 610-622.

Bernanke, Ben S (1983). "Irreversibility, Uncertainty, and Cyclical Investment". In: The Quarterly Journal of Economics 98.1, pp. 85-106.

Bloom, Nicholas (2009). "The Impact of Uncertainty Shocks". In: Econometrica 77.3, pp. 623-685.

- (2014). "Fluctuations in Uncertainty". In: Journal of Economic Perspectives 28.2, pp. 153-76.

Bloom, Nick, Stephen Bond, and John Van Reenen (2007). "Uncertainty and Investment Dynamics". In: The Review of Economic Studies 74.2, pp. 391-415.

Blundell, Richard and Stephen Bond (1998). "Initial Conditions and Moment Restrictions in Dynamic Panel Data Models". In: Journal of Econometrics 87.1, pp. 115-143.

Born, Benjamin and Johannes Pfeifer (2014). "Policy Risk and the Business Cycle". In: Journal of Monetary Economics 68, pp. 68-85.

Brennan, Michael J and Eduardo S Schwartz (1985). "Evaluating Natural Resource Investments". In: Journal of Business, pp. 135-157.

Carrière-Swallow, Yan and Luis F Céspedes (2013). "The Impact of Uncertainty Shocks in Emerging Economies". In: Journal of International Economics 90.2, pp. 316-325.

Choi, Sangyup (2017). "Variability in the Effects of Uncertainty Shocks: New Stylized Facts from OECD Countries". In: Journal of Macroeconomics.

Christiano, Lawrence, Cosmin Ilut, Roberto Motto, and Massimo Rostagno (2007). "Monetary Policy and Stock Market Boom-Bust Cycles". In: Manuscript, Northwestern University.

Colombo, Valentina (2016). "Economic Policy Uncertainty in the US: Does it Matter for the Euro Area?" In: Unpublished paper, University of Padova.

Dixit, Avinash K. and Robert S. Pindyck (1994). Investment under Uncertainty. Princeton University Press.

Fernández-Villaverde, Jesús, Pablo Guerrón-Quintana, Keith Kuester, and Juan Rubio-Ramìrez (2015). "Fiscal Volatility Shocks and Economic Activity". In: The American Economic Review 105.11, pp. 3352-3384.

Gilchrist, Simon, Jae W Sim, and Egon Zakrajšek (2014). "Uncertainty, Financial Frictions, and Investment Dynamics". In: National Bureau of Economic Research Working Paper No. 20038.

Grigoli, Francesco, Alexander Herman, and Klaus Schmidt-Hebbel (2014). "World Saving". In: International Monetary Fund Working Paper 16/160. 
Gulen, Huseyin and Mihai Ion (2015). "Policy Uncertainty and Corporate Investment". In: The Review of Financial Studies 29.3, pp. 523-564.

Hartman, Richard (1972). "The Effects of Price and Cost Uncertainty on Investment". In: Journal of Economic Theory 5.2, pp. 258-266.

Hassett, Kevin A and Gilbert E Metcalf (1999). "Investment with Uncertain Tax Policy: Does Random Tax Policy Discourage Investment". In: The Economic Journal 109.457, pp. 372-393.

Husted, Lucas, John Rogers, and Bo Sun (2016). "Measuring Cross Country Monetary Policy Uncertainty". In: Board of Governors of the Federal Reserve System IFDP Notes 2016-11-23.

IMF (2013). "Hopes, Realities, Risks". In: World Economic Outlook. Washington, DC.

Jordà, Òscar (2005). "Estimation and Inference of Impulse Responses by Local Projections". In: The American Economic Review 95.1, pp. 161-182.

Jurado, Kyle, Sydney C Ludvigson, and Serena Ng (2015). "Measuring Uncertainty". In: The American Economic Review 105.3, pp. 1177-1216.

Kamber, Guneş, Ozer Karagedikli, Michael Ryan, and Tugrul Vehbi (2013). "International Spillovers of Uncertainty Shocks: Evidence from a FAVAR". In: Unpublished paper.

Leahy, John V. and Toni M. Whited (1996). "The Effect of Uncertainty on Investment: Some Stylized Facts". In: Journal of Money, Credit and Banking 28.1, pp. 64-83.

McDonald, Robert and Daniel Siegel (1986). "The Value of Waiting to Invest". In: The Quarterly Journal of Economics 101.4, pp. 707-727.

Mongey, Simon and Jerome Williams (2016). "Firm Dispersion and Business Cycles: Estimating Aggregate Shocks Using Panel Data". In: Unpublished paper, Department of Economics, NYU.

Mumtaz, Haroon and Konstantinos Theodoridis (2015). "The International Transmission of Volatility Shocks: An Empirical Analysis". In: Journal of the European Economic Association 13.3, pp. $512-533$.

Novy, Dennis and Alan M Taylor (2014). "Trade and Uncertainty". In: National Bureau of Economic Research Working Paper No. 19941.

Oi, Walter Y (1961). "The Desirability of Price Instability Under Perfect Competition". In: Econometrica, pp. 58-64.

Paddock, James L., Daniel R. Siegel, and James L. Smith (1988). "Option Valuation of Claims on Real Assets: The Case of Offshore Petroleum Leases". In: The Quarterly Journal of Economics 103.3, pp. 479-508.

Pedroni, Peter (2013). "Structural Panel VARs". In: Econometrics 1.2, pp. 180-206.

Ramey, Garey and Valerie A Ramey (1994). "Cross-Country Evidence on the Link Between Volatility and Growth". In: National Bureau of Economic Research Working Paper No. 4959.

Rodrik, Dani (1991). "Policy Uncertainty and Private Investment in Developing Countries". In: Journal of Development Economics 36.2, pp. 229-242.

Romer, Christina D (1990). "The Great Crash and the Onset of the Great Depression". In: The Quarterly Journal of Economics 105.3, pp. 597-624.

Rossi, Barbara and Tatevik Sekhposyan (2015). "Macroeconomic Uncertainty Indices Based on Nowcast and Forecast Error Distributions". In: The American Economic Review 105.5, pp. 650 655. 


\section{Appendix A. Overview of EPU Sample}

Table A.1 provides more detailed information on the EPU data. For each country, we list the period for which the series are available and the number of newspapers used by Baker et al. (2016) to construct the EPU index.

Table A.1: EPU Sample

\begin{tabular}{lcc}
\hline Country & Sample Period & No. of Newspapers \\
\hline Australia & 1998Q1-2016Q4 & 8 \\
Brazil & 1991Q1-2016Q4 & 1 \\
Canada & 1985Q1-2016Q4 & 5 \\
Chile & 1993Q1-2016Q4 & 2 \\
China & 1995Q1-2016Q4 & 1 \\
France & 1987Q1-2016Q4 & 2 \\
Germany & 1993Q1-2016Q4 & 2 \\
India & 2003Q1-2016Q4 & 7 \\
Ireland & 1985Q1-2016Q4 & 1 \\
Italy & 1997Q1-2016Q4 & 2 \\
Japan & 1987Q1-2016Q4 & 4 \\
Korea & 1990Q1-2016Q4 & 6 \\
Netherlands & 2003Q1-2016Q4 & 5 \\
Russia & 1994Q1-2016Q4 & 1 \\
Singapore & 2003Q1-2016Q4 & trade-weighted average \\
& & of 18 other EPU indexes \\
Spain & 2001Q1-2016Q4 & 2 \\
Sweden & 1985Q1-2016Q4 & 4 \\
UK & 1997Q1-2016Q4 & 2 \\
US & 1985Q1-2016Q4 & 10 \\
\hline
\end{tabular}

Source: www.policyuncertainty.com. 


\section{Appendix B. Data Sources and Country Groups}

Table B.1 provides an overview of the variables used in the empirical analysis, along with the sources and scales.

Table B.1: Data Sources

\begin{tabular}{lll}
\hline Variable & Source & Scale \\
\hline Business confidence & OECD Main Economic Indicators & Index \\
Consumer confidence & OECD Main Economic Indicators & Index \\
Credit to the private sector & WB World Development Indicators & Percent of GDP \\
Economic Policy Uncertainty & www.policyuncertainty.com & Index \\
Inflation & IMF World Economic Outlook & Growth rate \\
GDP forecast disagreement & Baker and Bloom (2013) & Span \\
Old-age dependency ratio & WB World Development Indicators & Percent of working-age population \\
Urban population & WB World Development Indicators & Percent of population \\
Real deposit rate & IMF International Financial Statistics & Units \\
Real effective exchange rate & IMF International Financial Statistics & Growth rate \\
Real GDP per capita & IMF International Financial Statistics & Units (ln) \\
Real GDP & IMF World Economic Outlook & Growth rate \\
Real oil price & IMF Primary Commodity Price System & Units \\
Real govt. purchases & IMF World Economic Outlook & Growth rate \\
Real private consumption & IMF World Economic Outlook & Growth rate \\
Real private investment & IMF World Economic Outlook, & Growth rate \\
& OECD National Accounts database, & \\
Real public consumption & national accounts databases of specific countries & \\
Real public investment & IMF World Economic Outlook & Growth rate \\
Stock market returns & BMF World Economic Outlook & Growth rate \\
Stock market volatility & Baker and Bloom (2013) & Index \\
Terms of trade & IMF World Economic Outlook & Index \\
\hline
\end{tabular}


Table B.2 lists the countries in our dataset by region. We group countries according to the IMF regional departments.

Table B.2: List of Countries by Region

\begin{tabular}{|c|c|c|c|c|}
\hline \multicolumn{5}{|c|}{ Africa (AFR) } \\
\hline Angola & Comoros & Ghana & Mauritius & South Sudan \\
\hline Benin & Congo, Dem. Rep. of & Guinea & Mozambique & Swaziland \\
\hline Botswana & Congo, Rep. of & Guinea-Bissau & Namibia & São Tomé \& Príncipe \\
\hline Burkina Faso & Côte d'Ivoire & Kenya & Niger & Tanzania \\
\hline Burundi & Equatorial Guinea & Lesotho & Nigeria & Togo \\
\hline Cabo Verde & Eritrea & Liberia & Rwanda & Uganda \\
\hline Cameroon & Ethiopia & Madagascar & Senegal & Zambia \\
\hline Central African Rep. & Gabon & Malawi & Sierra Leon & Zimbabwe \\
\hline Chad & Gambia, The & Mali & South Africa & \\
\hline \multicolumn{5}{|c|}{ Asia Pacific (AP) } \\
\hline Australia & Fiji & Malaysia & Philippines & Timor-Leste \\
\hline Bangladesh & India & Maldives & Samoa & Tonga \\
\hline Bhutan & Indonesia & Mongolia & Singapore & Vanatu \\
\hline Brunei Darussalam & Japan & Myanmar & Solomon Islands & Vietnam \\
\hline Cambodia & Kiribati & Nepal & Sri Lanka & \\
\hline China, P.R.: Mainland & Korea & New Zealand & Tawain, Province of China & \\
\hline China, P.R.: Hong Kong & Lao, P.D.R. & Papua New Guinea & Thailand & \\
\hline \multicolumn{5}{|c|}{ Europe (EUR) } \\
\hline Albania & Denmark & Israel & Montenegro Rep. of & Slovak Rep. \\
\hline Austria & Estonia & Italy & Netherlands & Slovenia \\
\hline Belarus & Finland & Kosovo & Norway & Spain \\
\hline Belgium & France & Latvia & Poland & Switzerland \\
\hline Bosnia and Herzegovina & Germany & Lithuania & Portugal & Turkey \\
\hline Bulgaria & Greece & Luxembourg & Romania & Ukraine \\
\hline Croatia & Hungary & Macedonia, F.Y.R. & Russia & United Kingdom \\
\hline Cyprus & Iceland & Malta & San Marino & \\
\hline Czech Republic & Ireland & Moldova & Serbia & \\
\hline \multicolumn{5}{|c|}{ Middle East \& Central Asia (MC) } \\
\hline Afghanistan & Egypt & Kuwait & Oman & Tajikistan \\
\hline Algeria & Georgia & Kyrgyz Rep. & Pakistan & Tunisia \\
\hline Armenia & Iran & Lebanon & Qatar & Turkmenistan \\
\hline Azerbaijan & Iraq & Libya & Saudi Arabia & United Arab Emirates \\
\hline Bahrain & Jordan & Mauritania & Sudan & Uzbekistan \\
\hline Djibouti & Kazakhstan & Morocco & Syria & Yemen \\
\hline \multicolumn{5}{|c|}{ Western Hemisphere (WH) } \\
\hline Anguilla & Canada & Grenada & Nicaragua & Suriname \\
\hline Antigua and Barbuda & Chile & Guatemala & Panama & Trinidad \& Tobago \\
\hline Argentina & Colombia & Guyana & Paraguay & United States \\
\hline Bahamas, The & Costa Rica & Haiti & Peru & Uruguay \\
\hline Barbados & Dominica & Honduras & St. Kitts \& Nevis & Venezuela \\
\hline Belize & Dominican Rep. & Jamaica & St. Lucia & \\
\hline Bolivia & Ecuador & Mexico & St. Vincent \& the Grenadins & \\
\hline Brazil & El Salvador & Montserrat & Suriname & \\
\hline
\end{tabular}

